\title{
"Grammatical profiles and the interaction of the lexicon with aspect, tense, and mood in Russian"
}

\section{Abstract}

We propose the "grammatical profile" as a means of probing the aspectual behavior of verbs. A grammatical profile is the relative frequency distribution of the inflected forms of a word in a corpus. The grammatical profiles of Russian verbs provide data on two crucial issues: a) the overall relationship between perfective and imperfective verbs and $b$ ) the identification of verbs that characterize various intersections of aspect, tense and mood (TAM) with lexical classes. There is a long-standing debate over whether Russian aspectual "pairs" are formed only via suffixation (the Isačenko hypothesis) or whether they are formed via both suffixation and prefixation (the traditional view). We test the Isačenko hypothesis using data on the corpus frequency of inflected forms of verbs. We find that the behavior of perfective and imperfective verbs is the same regardless of whether the aspectual relationship is marked by prefixes or suffixes; our finding thus supports the traditional view.

Introspective descriptions of Russian aspect have often connected the use of particular inflectional forms with certain uses of aspect; for example, the use of imperative forms with the imperfective aspect to produce expressions that are very polite. Grammatical profiles make it possible to identify verbs that behave as outliers, presenting unusually large proportions of usage in parts of the paradigm. This analysis both gives substance to and extends previous introspective descriptions by identifying the verbs most involved in certain TAM-category interactions. On a methodological level, this study contributes to current discussions on the use of inflected forms vs. lemmas in corpus studies. Newman (2008) finds valuable information at the level of the inflectional form, and Gries (forthcoming) argues that inflectional forms do not necessarily provide a better basis for analysis than lemmas. We agree with them that the appropriate level of granularity is determined by both the language and the linguistic phenomenon under analysis. ${ }^{1}$

\subsection{Introduction}

\footnotetext{
${ }^{1}$ This research has been supported by a grant from the Norwegian Research Council for the "Exploring Emptiness" project and was conducted by members of the CLEAR (Cognitive Linguistics: Empirical Approaches to Russian) research group at the University of Troms $\varnothing$.
} 
We present a corpus study of the inflectional forms of Russian verbs, showing that these distributions, termed "grammatical profiles", have important implications for the description of Russian aspect. From a wider perspective this study also addresses the issue of granularity in corpus analysis.

The grammatical profile method is inspired by the work of Divjak and Gries (Divjak \& Gries 2006, Gries \& Divjak 2009) and can be described as a subset of the behavioral profile method they apply. Whereas Divjak and Gries employed a very comprehensive set of ID tags covering a large range of morphological, syntactic, semantic, and lexical factors, grammatical profiles focus only on morphological data as encoded in verb forms. This focus on morphology is motivated by Šteinfeldt's (1970: 28) observation that some verbs "are used in some forms much more frequently than others" and that differences in distribution are linked to aspect.

Gries (forthcoming) questions the use of data on inflectional forms in a usagebased analysis of corpus data. He is well-justified in pointing out that the presence of linguistic distinctions does not necessarily entail the presence of meaningful patterns. Just because we have data at a given fine-grained level of analysis does not mean that the given level is the optimal level. Gries' (forthcoming) study of verbs in the English ditransitive construction demonstrates that analysis at a more comprehensive level can give more insightful results than one at a fine-grained level. However, in other studies (Divjak \& Gries 2006, Gries \& Divjak 2009) we see that a fine-grained analysis is most appropriate. Newman and Rice (Newman 2008, Newman \& Rice 2006, Rice \& Newman 2005) present a series of studies of inflected forms of English verbs, both in their own right and in constructions such as going to, used to and VERB and VERB. They on the contrary find that the distribution of English inflected verb forms provide valuable insights that would be invisible at the lemma level. For example, while the meanings of English think, know, and mean appear very similar, their behavior at the inflectional level is very different (Newman 2008: 9-11). This disparity suggests that, even within a given language, the appropriate level of granularity for analysis is likely a function of the task at hand: whereas inflectional data may not be revealing for the ditransitive construction, it appears to be valuable for other English constructions.

An additional factor that likely plays a role is linguistic typology. A language that is heavily invested in inflection will offer more opportunities for a meaningful analysis at the level of the inflected form. English has only a handful of inflected forms for verbs. By contrast, the paradigm of a Russian imperfective verb contains up 
to 121 forms, while that of a perfective verb contains sixty-eight forms (cf. Table 1).

Since we analyze verb "pairs" (where a perfective verb and an imperfective verb share lexical meaning), this brings us to a total of 189 forms.

\begin{tabular}{|c|c|c|c|}
\hline subparadigm & $\begin{array}{l}\text { categories within } \\
\text { subparadigm }\end{array}$ & $\begin{array}{l}\text { imperfective } \\
\text { inflected } \\
\text { forms }\end{array}$ & $\begin{array}{l}\text { perfective } \\
\text { inflected } \\
\text { forms }\end{array}$ \\
\hline non-past & person, number & 6 & 6 \\
\hline past & gender, number & 4 & 4 \\
\hline infinitive & & 1 & 1 \\
\hline imperative & person, number & 4 & 4 \\
\hline gerund & tense & 2 & 1 \\
\hline participles & $\begin{array}{l}\text { case, gender, number, tense, } \\
\text { voice }\end{array}$ & 96 & 48 \\
\hline short form participles & gender, number, tense & 8 & 4 \\
\hline Totals & & 121 & 68 \\
\hline \multicolumn{4}{|c|}{ Illustrative example with the verb pair s/delat' 'do' } \\
\hline subparadigm & \multicolumn{3}{|c|}{$\begin{array}{l}\text { forms of } s / \text { delat' 'do' ( } s \text { / indicates that the form exists both } \\
\text { as an unprefixed imperfective and as a prefixed perfective) }\end{array}$} \\
\hline non-past & \multicolumn{3}{|c|}{$\begin{array}{l}\text { s/delaju }(1 \mathrm{sg}), \text { s/delaeš' }(2 \mathrm{sg}), \text { s/delaet }(3 \mathrm{sg}), \text { s/delaem } \\
(1 \mathrm{pl}), \text { s/delaete }(2 \mathrm{pl}), \text { s/delajut }(3 \mathrm{pl})\end{array}$} \\
\hline past & \multicolumn{3}{|c|}{ s/delal (Msg), s/delala (Fsg), s/delalo (Nsg), s/delali (pl) } \\
\hline infinitive & \multicolumn{3}{|c|}{ s/delat' } \\
\hline imperative & \multicolumn{3}{|c|}{$\begin{array}{l}\text { s/delaj }(\mathrm{sg}), \text { s/delajte }(\mathrm{pl} / \mathrm{pol}), \text { s/delaem }(\mathrm{pl} / \mathrm{incl}) \\
\text { s/delaemte }(\mathrm{pl} / \mathrm{incl} / \mathrm{pol})\end{array}$} \\
\hline gerund & \multicolumn{3}{|c|}{ delaja (non-p), s/delav (past) } \\
\hline participles & \multicolumn{3}{|c|}{$\begin{array}{l}\text { delajuščij (presact), s/delavšij (pastact), delaemyj } \\
\text { (prespass), s/delannyj (pastpass) }\end{array}$} \\
\hline short form participles & \multicolumn{3}{|c|}{ delaem (prespass), s/delan (pastpass) } \\
\hline abbreviations & \multicolumn{3}{|c|}{$\begin{array}{l}\text { 1, 2, 3: first, second, third person; sg, pl: singular, plural; M, F, N: } \\
\text { masculine, feminine, neuter; pol, incl: polite, inclusive; non-p: non- } \\
\text { past; presact, pastact, prespass,pastpass: present active, past active, } \\
\text { present passive, past passive }\end{array}$} \\
\hline
\end{tabular}

Table 1: The inflected forms of Russian verbs ${ }^{2}$

\footnotetext{
${ }^{2}$ The non-past forms express present tense for imperfective verbs but future tense for perfective verbs. Imperative forms distinguish first and second person, and singular and plural. The imperfective can have two gerunds, both the present gerund and the past gerund, whereas perfective verbs form only the past gerund. Imperfective verbs can have up to four participles (the present active, past active, present passive and past passive participles), whereas perfective verbs have two (the past active and past passive participles). Each participle in turn has a full complement of twenty-four adjectival paradigm forms, though there is some syncretism within this subparadigm. In addition, each passive participle has four short forms. Note that passives formed with the reflexive -sja are not included in this inventory. Of course different grammars might tally up the number of forms in different ways. Here we present the maximal number of forms that can be distinguished. There are some verbs with "defective" paradigms (cf. pobedit' 'conquer', which lacks a first person singular non-
} 
Following Gries' lead, however, we should be aware that the most detailed level of granularity available in our data is not necessarily the most optimal one. Figure 1 presents a relatively high-resolution overall grammatical profile for Russian. ${ }^{3}$ Given the variety of forms, grammatical profiles can be represented at varying levels of resolution. Full resolution, representing all 189 forms for a given lexical verb, yields cumbersome matrices where most of the cells have values equal or close to zero. Figure 1 collapses all of the adjectival subparadigms of participles as well as number, person and gender distinctions in finite forms.

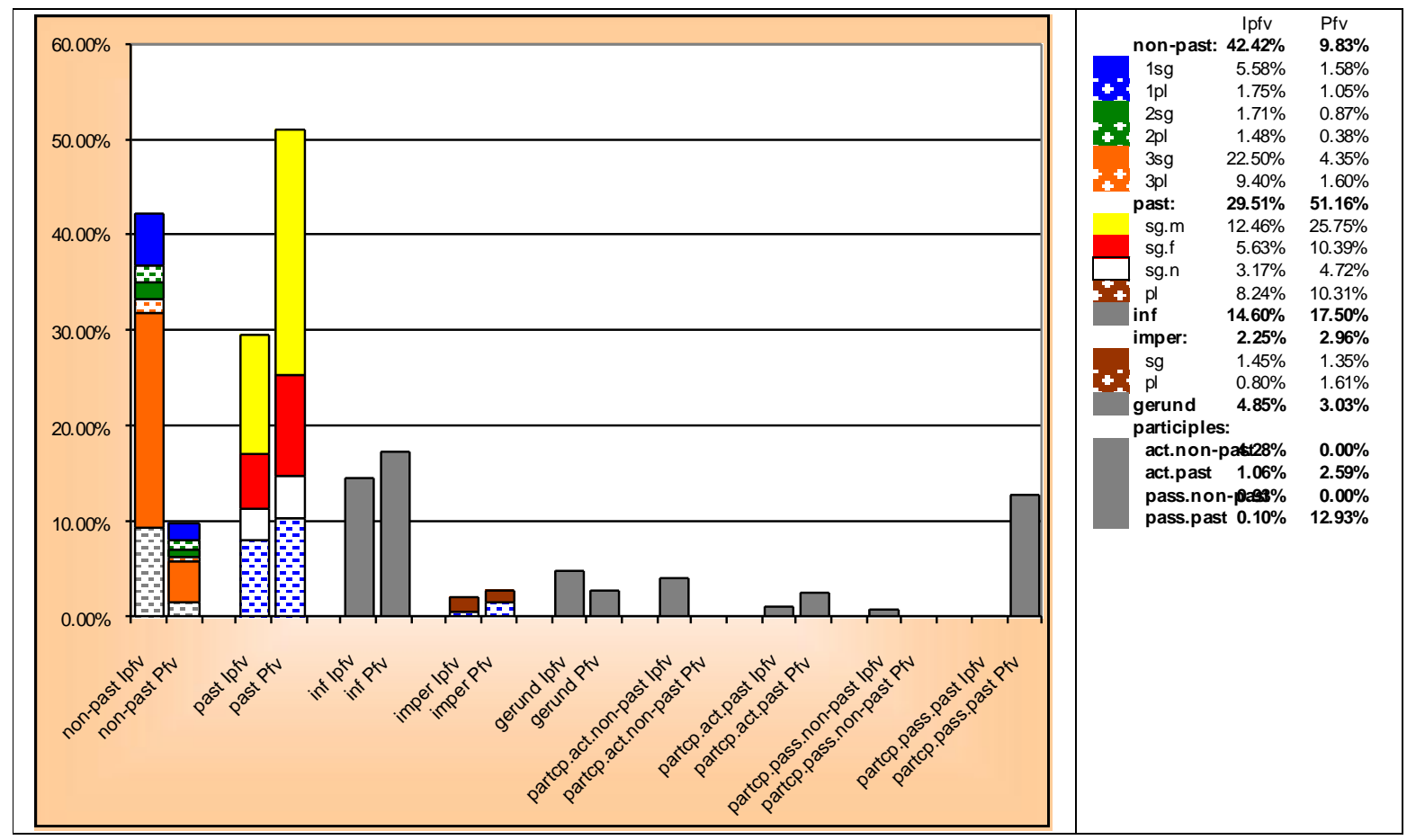

Figure 1: Distribution of forms in corpus data (patterns on bars refer to specific forms within subparadigms, as described in Table1)

As we see in Figure 1, the most relevant forms in the grammatical profiles for Russian verbs are the non-past, past, infinitive, and imperative, which yield approximately $85 \%$ of the total data for verbs. ${ }^{4}$ Given the fact that these subparadigms

past form), but these are exceptions. Note that our data takes into account only singleword forms, not paraphrastic forms such as, for example, the imperfective future with the auxiliary budu 'I will', budeš' 'you will', etc.

${ }^{3}$ Figure 1 presents frequency data available in a frequency dictionary of modern Russian (Lyashevskaya \& Sharoff 2010) that is based on a 92-million-word portion of the Russian National Corpus representing samples from 1950-2007.

${ }^{4}$ Gerunds and participles present a problem for comparing the behavior of aspectual pairs based on prefixation vs. suffixation, due to transitivity and morphological 
represent the most information-rich portion of the verbal paradigm, the grammatical profiles in this article offer a "medium" level of resolution, presenting only these four subparadigms and collapsing all information within each subparadigm. The medium level of resolution we have selected does not distinguish among categories not generally acknowledged to interact with aspect (person, number and gender), but focuses instead on those distinctions most likely to be relevant, namely finiteness, mood, and tense. We have thus calibrated our level of analysis to both the topic of our investigation (aspect) and the language of our study (Russian).

Since the topic of our analysis is Russian aspect, we offer a brief overview of relevant facts (2.0), focusing primarily on the Isačenko hypothesis (2.1) and special relationships between verbal subparadigms and aspect (2.2). We describe our two databases (3.0), one representing aspectual relationships marked by prefixation (3.1), and one representing aspectual relationships marked by suffixation (3.2). Our analysis (4.0) tests the Isačenko hypothesis (4.1) and examines outliers showing particularly strong relationships between aspect and verbal subparadigms (4.2). We conclude that grammatical profiles provide strong evidence that the perfective vs. imperfective distinction is the same regardless of how it is marked (via suffixation or prefixation), and that there are certain grammatical "idioms" in the interaction of aspect with inflection (5.0).

\subsection{Aspect in Russian}

Aspect in Russian is the topic of a vast literature that cannot be fully represented in this article. We focus instead on the most prominent works that serve as landmarks in the debate about whether aspectual pairs are formed via both prefixation and suffixation, or by suffixation alone. Before turning to this debate in 2.1, we offer some brief remarks on the morphological markers that signal aspect in Russian.

restrictions that would skew the data. Only transitive verbs can form passive participles. The morphological shape of an imperfective verb determines whether it can form certain gerunds and participles. Only simplex imperfectives can form past gerunds and past passive participles such as (ne) znavši '(not) having known [imperfective]' and brityj 'shaven [imperfective]'. Verbs with imperfectivizing suffixes are categorically prevented from forming past gerunds and past passive participles. Additionally one could justify excluding gerunds and participles on the grounds that they are peripheral members of the verbal paradigm, functioning instead as adverbs and adjectives. 
In Russian aspect is realized in all forms of all verbs. Given the ubiquity of aspect, verbs are usually recognized as being either perfective [p] or imperfective [i]. ${ }^{5}$ Russian uses a variety of morphological means to distinguish perfective and imperfective verbs, yielding three major patterns, plus some minor variations. The major patterns are:

1) Simplex verbs -- These are verbs consisting of a stem without any overt aspectual morphology, such as delat'[i] 'do, make'. The vast majority of these verbs are imperfective, though there is a handful simplex perfectives, such as dat'[p] 'give'; cf. Švedova et al. (1980: 590) who list only eleven simplex perfectives in Russian.

2) Prefixed verbs -- These are verbs consisting of a prefix added to a stem, such as sdelat'[p] 'do, make' and peredelat'[p] 'redo', where the prefixes $s$ - and perehave been added to delat'[i] 'do, make'. With very few exceptions, these verbs are perfective. $^{6}$ There are nineteen such prefixes (cf. Krongauz 1998), and they are commonly termed "perfectivizing prefixes" due to their function in the aspect system. For the purposes of this study, we need to distinguish among two subtypes: Natural Perfectives (with the same meaning as the simplex imperfective, like sdelat'[p] 'do, make'), and Specialized Perfectives (with a different meaning from the simplex imperfective, like peredelat'[p] 'redo'). ${ }^{7}$

3) Prefixed and suffixed verbs -- These are verbs consisting of a prefix, a stem, and a suffix, such as peredelyvat'[i] 'redo', which has the prefix pere-, the root -dela-, and the suffix $-y v a(j)$. These verbs involve the same nineteen prefixes (plus a twentieth, $d o-)$, plus three "imperfectivizing" suffixes: $-a(j),-v a(j)$, or $-i / y v a(j)$. It is primarily only Specialized Perfectives that admit such secondary imperfectivization.

\footnotetext{
${ }^{5}$ While bi-aspectual verbs do exist, most scholars agree that they are unambiguous in context and they also tend to develop aspectual morphology, as for example the biaspectual verb rekomendovat'[p/i] 'recommend' which has a prefixed perfective otrekomendovat' despite the fact that the unprefixed form can serve as a perfective. For a discussion and references, see Janda 2004: 523 and 2007: 637-638.

${ }^{6}$ Most of the exceptions involve the indeterminate stems of motion verbs such as xodit'[i] 'walk', which can form both perfective (cf. zaxodit'[p] 'begin to walk') and imperfective (cf. proxodit'[i] 'walk through/past') verbs when prefixed. For more discussion of this group of exceptions, see Janda 2010.

${ }^{7}$ The distinction between Natural Perfectives and Specialized Perfectives is presented in detail in Janda 2007, where two further types of perfectives are also distinguished. Note also that "the same meaning" here refers to lexical meaning, that is, meaning apart from aspectual differences.
} 
There are additionally some minor patterns, which we list here but do not discuss further:

i) Suffixed verbs -- There are two subtypes here. The first subtype adds one of the imperfectivizing suffixes to a simplex perfective, yielding an imperfective such as davat'[i] 'give'. There are three such verbs (devat'[i] 'put' and padat'[i] 'fall' in addition to davat'[i]); the remaining simplex perfectives are aspectually paired via suppletion. Another subtype involves the addition of the $-i / y v a(j)$ suffix to produce habitual verbs such as govarivat'[i] 'talk, say habitually' (from govorit'[i] 'talk, say'). The number of such habitual verbs in Russian is very small and the type is unproductive (cf. Danaher 2003: 31). Both types of verbs are too marginal to be included in the current study.

ii) Semelfactive suffixed verbs -- These verbs contain a verbal stem plus the semelfactive perfectivizing suffix $-n u$, as in čixnut'[p] 'sneeze once' (formed from čixat'[i] 'sneeze'). There are approximately three hundred such perfective verbs in Russian; for more discussion, see Dickey \& Janda 2009. These verbs have a semelfactive meaning and thus do not normally serve as perfective "partners" for the imperfectives they are derived from. Since this study specifically examines the "purely aspectual" relationships of pairs, the semelfactive suffixed verbs are beyond the scope of our analysis.

iii) Semelfactive prefixed and suffixed verbs -- These verbs add a prefix to the semelfactive suffixed type, yielding verbs such as vyprygnut'[p] 'jump out once'. There appear to be under two hundred such verbs in Russian (for a detailed study, see Makarova \& Janda 2009). Like the semelfactive suffixed verbs, these verbs do not form aspectual pairs and are thus not included in the present study.

While "prefix stacking" is possible in Russian, yielding verbs with multiple prefixes, this type is rather marginal and generally forms perfectives such as poperepisyvat' $[\mathrm{p}]$ 'spend a while rewriting, 8 There are furthermore a few dozen verbs that form suppletive pairs, such as govorit'[i] - skazat'[p] 'talk, say'. These are not systematic types and are therefore likewise excluded from the current study.

\subsection{Isačenko hypothesis}

\footnotetext{
${ }^{8}$ This verb can be broken down as po-pere-pis-yva-t', where po- and pere- are prefixes, pis- is the root, $-y v a(j)$ is a suffix, and $-t$ ' is a desinence. Note that an alternative interpretation of this word is as a distributive meaning 'rewrite all of'.
} 
The three major morphological patterns of Russian verbs offer two options for forming aspectual pairs, namely:

a) Via prefixation of a simplex imperfective, yielding pairs such as delat'[i] sdelat' $[\mathrm{p}]$ 'do, make' (henceforth " $\mathrm{p}$-partners" since they involve prefixation); and

b) Via suffixation of a prefixed perfective, yielding pairs such as peredelat' $[\mathrm{p}]$ - peredelyvat' [i] 'redo' (henceforth "s-partners" since they involve suffixation). Whereas most traditional analyses (Vinogradov 1938, Šaxmatov 1941, Švedova et al. 1980, Bondarko 1983, Čertkova 1996, Anna Zaliznjak \& Šmelev 2000) plus virtually all dictionaries and textbooks accept both kinds of pairs, one of the most prominent scholars in the field of Russian aspect, Isačenko (1960: 130-175), argues that only the second kind of pair, formed via suffixation, represents a purely aspectual relationship in Russian. Isačenko's argument is based on introspective claims that a) the addition of a prefix always brings associated meaning to the prefixed verb thus making it nonidentical in meaning to the simplex imperfective, and that b) the prefixed perfective is not a perfective "replacement" for the simplex imperfective in all contexts. Isačenko analyzes the "tests" that scholars have proposed for identifying pairs created via prefixation, presents counterexamples, and also shows that the proponents of such tests do not agree on the results either. The Isačenko hypothesis receives direct support from Andrej Zaliznjak (1980: 6, 136) who implements this distinction throughout his famous grammatical dictionary, recognizing only aspectual pairs consisting of a prefixed perfective and a suffixed secondary imperfective. In a recent authoritative grammar of Russian, Timberlake (2004: 410-411) takes an intermediary stance on the question of whether there are aspectual pairs formed via prefixation. According to Timberlake, prefixed perfectives and their secondary imperfectives fulfill the criteria of aspectual pairs, but simplex imperfectives and corresponding prefixed perfectives form "near-partners".

There are thus two opposed hypotheses on the formation of aspectual pairs in Russian:

(1) Traditional Hypothesis: Aspectual pairs are formed either via prefixation of a simplex imperfective or via suffixation of a prefixed perfective.

(2) Isačenko Hypothesis: Aspectual pairs are formed only via suffixation of a prefixed perfective.

The logical corollaries to these two hypotheses are as follows: 
(1a) Corollary to Traditional Hypothesis: The two kinds of pairs (p-partners and spartners) are identical in function and should behave identically.

(2a) Corollary to Isačenko Hypothesis: Prefixed perfectives paired with suffixed imperfectives (s-partners) are the only pairs in the system; since simplex imperfectives and corresponding prefixed perfectives (p-partners) represent a different relationship, they should behave differently.

The aim of this study is to test the two hypotheses based on the logic of the corollaries. We will examine available data in order to compare the behavior of $\mathrm{p}$ partners with s-partners. If our data shows no difference in the behavior of p-partners in comparison with s-partners, that is evidence in support of the traditional hypothesis. If our data shows a difference in the behavior of p-partners in comparison with spartners, that is evidence in support of the Isačenko hypothesis. In order to test the hypotheses, we use data on the corpus frequency of inflected forms of verbs. But before turning to the data and analysis, it is necessary to justify the choice of subparadigms on theoretical grounds.

\subsection{Aspect and the subparadigms}

As mentioned in section 1.0, there are solid distributional grounds for excluding the gerunds and participles from this study. However, the remaining subparadigms of the Russian verb are not merely a convenient residue, for they also represent exactly the categories that we most expect to interact with aspect in significant ways, namely tense (non-past and past) and mood (infinitive, imperative, and indicative ${ }^{9}$ ). The special relationship between aspect, tense, and mood (the "TAM" categories) is wellestablished cross-linguistically (Comrie 1976, Chung \& Timberlake 1985, Binnick 1991, Bybee et al. 1994, Nuyts 2001 \& 2007), and is also central to the Russian verbal system. Note that Timberlake's (2004) reference grammar of Russian has only seven chapters, but one of them is titled "Mood, tense, and aspect" and extends over seventy-three pages, with numerous detailed descriptions of how both mood and tense interact with aspect. Timberlake (2004: 373) identifies three moods expressed morphologically in Russian: realis (non-past and past inflected forms), imperative, and infinitive. The imperative mood is claimed to be dominated by perfective verbs, though certain contexts (negation, politeness, insistence) may prefer imperfective

\footnotetext{
${ }^{9}$ Subjunctive mood is not expressed inflectionally in Russian, but by paraphrastic means.
} 
verbs (Timberlake 2004: 374-376; cf. also Pul'kina \& Zaxava-Nekrasova 1977: 284285, Wade 1992: 303-304). The aspect of the infinitive is often influenced by modal markers (nelzja 'it is not permitted', nado 'it is necessary'), and only imperfective infinitives are permitted in conjunction with phasal verbs (načat' 'begin', perestat' 'stop') and the future auxiliary (budu 'I will' and remaining forms of the paradigm; Timberlake 2004: 360-370; cf. Pul'kina \& Zaxava-Nekrasova 1977: 272-276, Švedova et al. 1980: 605, Wade 1992: 306-312). In terms of tense, Russian verbs distinguish only non-past from past in their inflection. Aspect disambiguates the present (imperfective non-past) from the future (perfective non-past), although there are other uses of both aspects in the non-past (such as the historical present expressed primarily by imperfective non-past forms and the habitual-chain construction, where perfective non-past signals repeated sequences of events; cf. Dickey 2000: 126-154, 52-68 and Comrie 1976: 73-78). Overall, there seems to be an association of the imperfective with present [= non-past $]$ tense and the perfective with past tense (Comrie 1976: 83-84).

This array of interactions between aspect and the inflectional subcategories of Russian verbs has not been examined from the perspective of a large-scale corpus analysis. In this study we use data that compares the frequencies of the subparadigms of perfective and imperfective verbs to test the traditional vs. Isačenko hypotheses, and also to shed light on some of the specific claims about the interaction of tense, mood, and aspect in Russian. In order to get an overall perspective on the TAM and inflectional interactions, we first look at data that aggregates the behavior of as many verbs as possible (3.0-4.1). We then zero in on specific TAM combinations, and at this level reveal the behaviors of individual verbs (4.2).

\subsection{Databases}

For the purpose of this study, we constructed two databases, one with data about ppartners (simplex imperfectives paired with prefixed perfectives) and one with data about s-partners (prefixed perfectives and suffixed secondary imperfectives). Both databases are based on the Modern subcorpus (1950-2007) of the Russian National Corpus (www.ruscorpora.ru; henceforth "RNC", the source of all examples herein), which contains 92 million words. Each database includes information about the frequency of the following grammatical forms: 
- Ipfv_NonPast: the sum of $1 \mathrm{sg}, 2 \mathrm{sg}, 3 \mathrm{sg}, 1 \mathrm{pl}, 2 \mathrm{pl}, 3 \mathrm{pl}$ imperfective non-past frequencies

- Ipfv_Past: the sum of masculine, feminine, neuter singular and plural imperfective past form frequencies

- Ipfv_Inf: imperfective infinitive form frequency

- Ipfv_Imper: the sum of $2 \mathrm{sg}, 2 \mathrm{pl}, 1 \mathrm{pl}(-m t e)$ imperfective imperative form frequencies

- Pfv_NonPast: the sum of $1 \mathrm{sg}, 2 \mathrm{sg}, 3 \mathrm{sg}, 1 \mathrm{pl}, 2 \mathrm{pl}, 3 \mathrm{pl}$ perfective non-past form frequencies

- Pfv_Past: the sum of masculine, feminine, neuter singular and plural Perfective past form frequencies

- Pfv_Inf: Perfective infinitive form frequency

- Pfv_Imper: the sum of $2 \mathrm{sg}, 2 \mathrm{pl}, 1 \mathrm{pl}(-m t e)$ Perfective imperative form frequencies

Because there are rare verbs represented in the RNC that might misrepresent the data, we applied a frequency threshold in the construction of both databases in order to ensure that our data was representative of overall trends in Russian. We removed from the study all potential pairs where either the total frequency of finite perfective forms or the total frequency of finite imperfective forms in the RNC is less than 100 (e.g. arkanit'[i] 'lasso' with only 2 imperfective forms and its perfective partner zaarkanit' $[\mathrm{p}]$ with only 21 forms). There were several additional measures that needed to be taken in order to create databases that would facilitate accurate and meaningful comparisons. These measures are described in the following two subsections.

\subsection{Database of p-partners (simplex imperfectives \& prefixed perfectives)}

The first task in constructing this database was to obtain a list of all p-partners. The "Exploring Emptiness" database at the University of Tromsø is just such a list. The "Exploring Emptiness" database contains 1981 aspectual pairs, each consisting of an imperfective base verb and the corresponding Natural Perfective, aggregated from two dictionaries (Evgen'eva 1999 and Ožegov \& Švedova 2001) and a list (Cubberly 
1982) and acknowledged by a panel of native speakers. ${ }^{10}$ From this list, we removed the following items in order to reduce "noise" in the database:

a) verbs that are not attested in the RNC or do not meet the criterion of the above-mentioned frequency threshold;

b) verbs for which no unique pair could be identified due to the existence of two or more prefixed forms (for example, valit'[i] 'topple', which has two perfectives with two different prefixes: svalit' $[\mathrm{p}]$ and povalit' $[\mathrm{p}]$; verbs of this sort would yield multiple perfectives for a given imperfective, misrepresenting the data);

c) verbs with aspectual relations that were either irregular or could not be accurately disambiguated in our data (this includes biaspectual verbs like arendovat' $[\mathrm{i} / \mathrm{p}]$ 'lease' and verbs with aspectual homophony like sxodit'[i/p] 'descend[i]; walk someplace and come back once[p]', and verbs like sžat'[p] which is homophonous in much of its paradigm, meaning either 'squeeze' or 'harvest'). ${ }^{11}$

It was necessary to take the above measures in order to avoid collecting ambiguous data and to make the two databases parallel to each other. The "cleaned" version of the p-partner database includes only candidate partners that consist of just two uniquely identifiable verbs, making it parallel with the s-partner database, where challenges to unique pairedness are very rare. Aspectual pairs formed by suffixation almost never present problems such as multiple aspectual markers (avoided by measure b) and unambiguatable homophonous forms (avoided by measure c). After the application of these measures, the database of p-partners contains over 1.6 million datapoints representing 264 aspectual pairs and the frequencies of their subparadigms. This data reliably reflects the p-partners and facilitates straightforward comparison with parallel data for s-partners.

\subsection{Database of s-partners (prefixed perfectives \& suffixed secondary imperfectives)}

As with the database of p-partners, the first task was to get a list of all potential spartners. This was done on the combined basis of Zaliznjak 1980 (who lists s-partners uniquely) and the RNC, yielding 19,208 pairs. However, many of these verbs are of

\footnotetext{
${ }^{10}$ The panel included members of the "Exploring Emptiness" research group at the University of Tromsø: Olga Lyashevskaya, Julia Kuznetsova, Svetlana Sokolova, and Anastasia Makarova.

${ }^{11}$ Given that we had nearly six million verb forms in our database, it was not possible to undertake such disambiguation by hand.
} 
low frequency and in a few rare cases some prefixed verbs can use more than one suffix to derive imperfectives. ${ }^{12}$ When the above-mentioned frequency threshold was applied and verbs with multiple suffixed partners were removed, the database of spartners was reduced to 1,311 pairs.

We note in addition that there is a certain overlap in the two databases due to the existence of homophones. For example, vyrasti[p] can either mean 'grow (up)', in which case it is the prefixed perfective p-partner of rasti[i] 'grow'; or it can mean 'develop into; grow out of', in which case it has a suffixed secondary imperfective (spartner) in vyrastat' $[\mathrm{i}] .{ }^{13}$ There are thirty-eight verbs involved in this overlap.

\subsection{Analysis}

The data described in 3.1-3.2 yield a total of 1,575 pairs of verbs, which represent $5,951,250$ verb forms in the RNC. Our analysis is based on this data. The sheer size of this mass of data presents certain problems for statistical analysis that must be handled responsibly. Before proceeding to the statistical analysis it is necessary to understand the relationship between sample size and effect size. With a large sample size, one has so much statistical power that one runs the risk of detecting effects that are so small as to not be meaningful (cf. Baayen 2008: 114-16; Tabachnik \& Fidell 2007: 54-55). The chi-square model is designed to detect significant differences in distributions. The more data one has available, the better chi-square is at detecting ever smaller differences; as the data heads toward infinity, the differences that can be detected are infinitely small. The Cramer's V measure has been developed in order to check on the size of the effect detected by a chi-square test, and is especially important in situations when there are thousands or millions of datapoints. Cramer's $\mathrm{V}$ balances the chi-square value against the number of datapoints, giving a measure that can theoretically vary between 0 and 1 . It is customary to consider a Cramer's $\mathrm{V}$ value of 0.5 as representing a large effect, 0.3 as representing a moderate effect, and 0.1 as representing a small effect (Cohen 1988: 215-271; Cohen et al. 2003: 182;

\footnotetext{
${ }^{12}$ An example of a prefixed perfective with multiple suffixed imperfective partners is zagotovit'[p] 'stockpile' with the derived imperfectives zagotovljat'[i] and zagotavlivat'[i].

${ }^{13}$ Though there is semantic overlap in such verbs, usually there is some distinction between the two imperfectives. For example, rasti[i] 'grow' is mainly associated with concrete uses, largely in reference to plants, whereas vyrastat' [i] 'develop into; grow out of' is more likely to be used in metaphorical contexts.
} 
King \& Minium 2008: 327-330). In the statistical analyses presented in 4.1 we cite a Cramer's V value alongside all chi-square figures in order to safeguard against reporting significant values that are too small to deserve recognition. Section 4.1 presents evidence that the grammatical profiles of p-partners and s-partners do not deviate from the overall behavior of perfective and imperfective verbs in Russian, nor do the two types of partners differ from each other. Section 4.2 examines specific TAM combinations and the individual verbs that are strongly attracted to such combinations.

\subsection{Grammatical profiles of aspectual pairs}

Aggregating the two databases of p-partners and s-partners gives us a big-picture perspective on the overall behavior of imperfective vs. perfective verbs. Table 2 compares the grammatical profiles of imperfective verbs of both types with the grammatical profiles of perfective verbs of both types. The left-hand portion of Table 2 gives the grammatical profiles of imperfective verbs, citing first non-past, then past, then infinitive and then imperative forms. Both the raw frequencies and the relative frequencies are cited, and the latter add to $100 \%$ for imperfective verbs. The righthand portion of Table 2 gives parallel information for the perfective verbs.

\begin{tabular}{|c|c|c|c|c|c|c|c|c|}
\hline & \multicolumn{4}{|c|}{ Imperfective } & \multicolumn{4}{|c|}{ Perfective } \\
\hline & $\mathrm{Ipfv}_{-}$ & $\mathrm{Ipfv}_{-}$ & $\mathrm{Ipfv}_{-}$ & Ipfv & $\mathrm{Pfv}_{-}$ & $\mathrm{Pfv}_{-}$ & $\mathrm{Pfv}_{-}$ & $\mathrm{Pfv}_{-}$ \\
\hline & NonPast & Past & Inf & Imper & NonPast & Past & Inf & Imper \\
\hline both p- & $1,1,330,016$ & 9915,374 & $\begin{array}{l}482,860 \\
\end{array}$ & $\begin{array}{l}75,717 \\
\end{array}$ & $\begin{array}{l}375,170 \\
\end{array}$ & $101,972,287$ & 26888,317 & 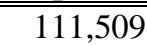 \\
\hline $\begin{array}{l}\& \text { s- } \\
\text { partners }\end{array}$ & $47.4 \%$ & $32.6 \%$ & $17.2 \%$ & $2.7 \%$ & $11.9 \%$ & $62.7 \%$ & $21.9 \%$ & $3.5 \%$ \\
\hline
\end{tabular}

Table 2: Grammatical profiles of imperfective vs. perfective verbs

Table 2 shows that the distribution of forms is different for the two aspects. The non-past forms dominate the distribution of imperfective verbs, whereas the past forms dominate the distribution of perfective verbs. The chi-square test (chi-squared $=$ 947756, $\mathrm{df}=3$, $\mathrm{p}$-value $<2.2 \mathrm{e}-16$ ) indicates that the differences between imperfective and perfective verbs are significantly different, and the effect size Cramer's V value is 0.399 , which is thus between "medium" $(0.3)$ and "large" $(0.5)$. Therefore the effect of aspect on grammatical profiles in Russian is both significant and robust. This finding is in keeping with Comrie's (1976: 84) theoretical conjecture on the relationship between tense and aspect. Thus our empirical study confirms this assumed relationship on the basis of a large database. 
Next we break the data down according to the p-partner and s-partner databases, and here we see that the factor of whether the aspectual relationship is based on prefixation or suffixation does not yield an appreciable effect. Table 3 presents the same data as in Table 2, now broken down according to p-partners (in the top half of the Table) vs. s-partners (in the bottom half of the Table). As in Table 2, Table 3 reports both the raw and relative frequencies, and the latter adds to $100 \%$ in each quadrant. The upper left quadrant shows forms of p-partner imperfectives (simplex imperfectives) and can be compared to the lower left quadrant, which shows forms of s-partner imperfectives (secondary imperfectives of Specialized Perfectives). A parallel comparison can be made across the right-hand quadrants, with the upper quadrant showing forms of p-partner perfectives (prefixed Natural Perfectives), as compared with the lower quadrant showing forms of s-partner perfectives (prefixed Specialized Perfectives).

\begin{tabular}{|c|c|c|c|c|c|c|c|c|}
\hline & \multicolumn{4}{|c|}{ Imperfective } & \multicolumn{4}{|c|}{ Perfective } \\
\hline & $\mathrm{Ipfv}_{-}$ & Ipfv_- & $\mathrm{Ipfv}_{-}$ & $\mathrm{Ipfv}_{-}$ & $\mathrm{Pfv}_{-}$ & $\mathrm{Pfv}_{-}$ & $\mathrm{Pfv}_{-}$ & $\mathrm{Pfv}_{-}$ \\
\hline $\begin{array}{l}\text { p- } \\
\text { partners }\end{array}$ & $\begin{array}{r}475,893 \\
43 \% \\
\end{array}$ & $\begin{array}{r}397,409 \\
35.9 \%\end{array}$ & $\begin{array}{r}195,926 \\
17.7 \%\end{array}$ & $\begin{array}{r}36,427 \\
3.3 \% \\
\end{array}$ & $\begin{array}{r}72,439 \\
13.7 \% \\
\end{array}$ & $\begin{array}{r}317,570 \\
60.1 \% \\
\end{array}$ & $\begin{array}{r}114,460 \\
21.6 \%\end{array}$ & $\begin{array}{r}24,280 \\
4.6 \% \\
\end{array}$ \\
\hline $\begin{array}{l}\text { s- } \\
\text { partners }\end{array}$ & $\begin{array}{r}854,123 \\
50.3 \%\end{array}$ & $\begin{array}{r}517,965 \\
30.5 \%\end{array}$ & $\begin{array}{r}286,934 \\
16.9 \%\end{array}$ & $\begin{array}{r}39,290 \\
2.3 \%\end{array}$ & $\begin{array}{r}302,731 \\
11.6 \%\end{array}$ & $\begin{array}{r}1,654,717 \\
63.2 \%\end{array}$ & $\begin{array}{r}573,857 \\
21.9 \%\end{array}$ & $\begin{array}{r}87,229 \\
3.3 \%\end{array}$ \\
\hline
\end{tabular}

Table 3: Frequencies of verb forms extracted from the RNC

Figure 2 is a graphic representation of this data using the relative frequencies in order to put the data on the same scale for meaningful comparison. This visualization suggests that there is very little difference between the behavior of the p-partners (dark grey) and the s-partners (light grey) in terms of how aspect interacts with their grammatical profiles. This lack of difference is confirmed by statistical tests.

Imperfective 


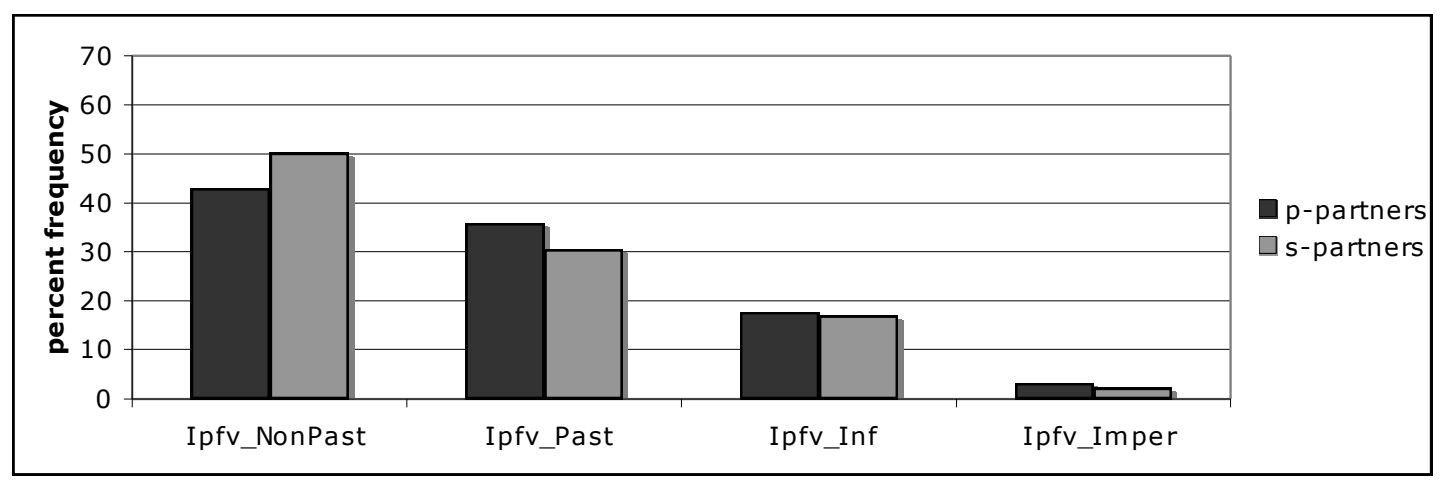

Perfective

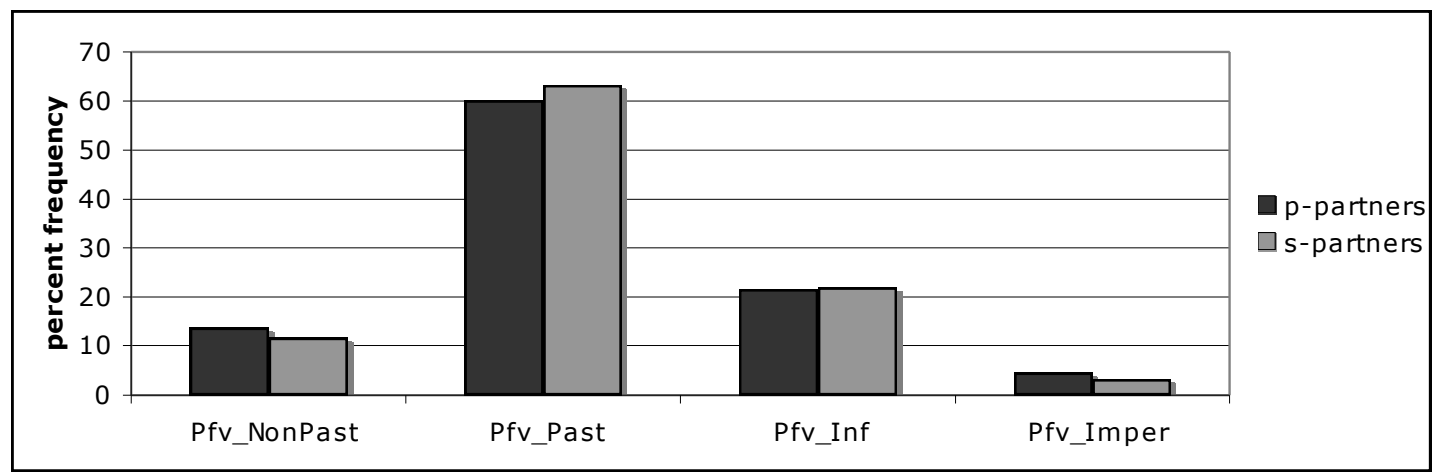

Figure 2: Distribution of p-partner (dark grey) and s-partner (light grey) forms

A chi-square test comparing the behavior of p-partner vs. s-partner imperfectives (cf. top portion of Figure 2) yields a result that is statistically significant (chi-squared $=16155.13, \mathrm{df}=3, \mathrm{p}$-value $<2.2 \mathrm{e}-16$ ), but tiny, since the Cramer's V value (0.076) does not reach the threshold for a small effect. We get parallel results when we compare the behavior of p-partner and s-partner perfectives (cf. bottom portion of Figure 2). Again the result is statistically significant (chi-squared $=$ 4365.078, $\mathrm{df}=3$, $\mathrm{p}$-value $<2.2 \mathrm{e}-16)$, but the effect size (Cramer's $\mathrm{V}=0.037$ ) falls far short of the threshold for a small effect. In both cases, we are dealing with a situation where the large quantity of data makes it too easy for the chi-square test to report results as significant. The Cramer's V test safeguards us from recognizing an effect that is so unimportant that it cannot even be regarded as "small". We must conclude that there is no appreciable difference between the distributions of imperfective vs. perfective forms that would distinguish p-partners from s-partners.

Looking again at Figure 2, we see that the overall distribution of forms confirms the parallelism of the p- and s-partners. In the imperfective subparadigm, both $\mathrm{p}$ - and s-partners show the same pattern, namely that the non-past forms have the highest frequency, followed by the past forms, then the infinitive forms and finally the 
imperative forms. The perfective subparadigm continues the parallelism precisely: the highest frequency for both p- and s-partners is among past forms, followed by infinitives, then non-past, and finally imperatives.

In short, the distribution of forms is basically the same, regardless of whether the verbs are p-partners or s-partners. This finding supports the traditional hypothesis that aspectual pairs are formed in Russian both by means of prefixation and by means of suffixation. Whereas there might be another measure that would find a difference between these two morphologically distinct types, our study did not find one. Thus we do not find support for the Isačenko hypothesis. This of course does not rule out the possibility that there might be other factors that would support the Isačenko hypothesis.

In the following section we use the same data to examine verbs with unusual distributions. Given the fact that there is no real difference between the p-partners and the s-partners, our discussion of outliers in that section merges data from both morphological types.

\subsection{Outliers}

Given Šteinfeldt's (1970) finding that verbs vary in the frequency distributions of their paradigm forms, we expect individual verbs to behave differently in terms of their grammatical profiles. Because aspect, tense, and mood have semantic import, we also expect that differences in behavior are connected to the semantics of verbs. For this reason, we expect that particular TAM combinations will be associated with particular groupings of verbs. Our hypothesis is thus that verbs at the top of the distribution for each TAM combination is there for a reason, namely because their semantic content is particularly appropriate for that paradigm slot. This section is devoted to testing this hypothesis.

This section is divided into eight subsections according to the eight combinations of aspect with tense or mood. Here we present new empirical data on the interaction of TAM categories in Russian and verbal semantics, since this is the first attempt to identify groups of verbs representing various hypothesized phenomena.

In each subsection, we first state a hypothesis based on previous scholarship. We then identify individual verbs that behave as outliers, discuss their properties, and compare them with other verbs that are not outliers. Here we define outliers as the 
points that are displaced beyond 1.5 times the interquartile range (the interquartile range includes $50 \%$ of a distribution, with one quartile above the median and one below, cf. King \& Minium 2008: 71-72, 76-78). All of the following subsections will focus only on verbs that meet this criterion. Each subsection is illustrated by a figure showing a boxplot of the distribution of verbs. The median is the boldfaced line inside the box, the edges of the box represent the edges of the interquartile range, the whiskers extend to \pm 1.5 times the interquartile range, and the small circles represent outliers (Baayen 2008: 30). The actual outlier verbs are presented in tables that give the verb, its gloss, the absolute frequency of relevant forms, and the percentage of total forms for that verb in the given subparadigm.

Since this section focuses on outliers, the order of presentation reflects the number of outliers found in the various subparadigms of imperfective and perfective verbs. We find the most outliers among the imperative forms, followed by the nonpast, the infinitive, and the past, and the discussion follows this cline. While the tables in each section list verbs in their infinitive forms, they are cited in appropriate forms from the given subparadigm in the discussion.

\subsubsection{Imperfective imperative}

Linguistic analyses of Russian aspect make three claims about the use of imperfective aspect with imperatives: that imperfective is associated with negation when it is categorical, that imperfective is used in order to show politeness, and that imperfective is also used to signal urgency or insistence (cf. Bondarko \& Bulanin 1967: 127-128; Padučeva 1996: 12-17; Švedova et al. 1980: 624; Timberlake 2004: 374-375) ${ }^{14}$. The latter two claims, namely that imperfective imperatives can be used to signal both politeness and rudeness, seem contradictory. Šatunovskij $(2002,2009)$ suggests a solution to this problem. According to Šatunovskij, the underlying motive for both the polite and rude uses has to do with the hearer's understanding that the proposed action should take place. If the hearer understands that $\mathrm{s} / \mathrm{he}$ is supposed to act, then imperfective is required, regardless of whether the use is construed as polite or rude. In certain contexts, like visiting a friend, the hearer already knows a lot about what will happen: s/he will come in, sit down, eat or drink something, etc. The

\footnotetext{
${ }^{14}$ In identifying pragmatic import (politeness, rudeness, urgency, etc.), we follow the conventions of the standard grammars of Russian cited here and elsewhere in this article.
} 
speaker's directions in these contexts are interpreted as polite. In other contexts, the hearer has failed to act appropriately, despite clear indications, and the speaker's choice of imperfective aspect is rude because it implies insistence. In still other cases the hesitation is less problematic and the speaker merely offers encouragement for something the hearer already intends to do: this yields imperfective imperatives with neutral affect. Our data support Šatunovskij's analysis, but also extend it.

Our hypothesis is thus that we expect the imperfective imperative to be associated with verbs that are used pragmatically to express politeness and urgency, and also in contexts of categorical negation.

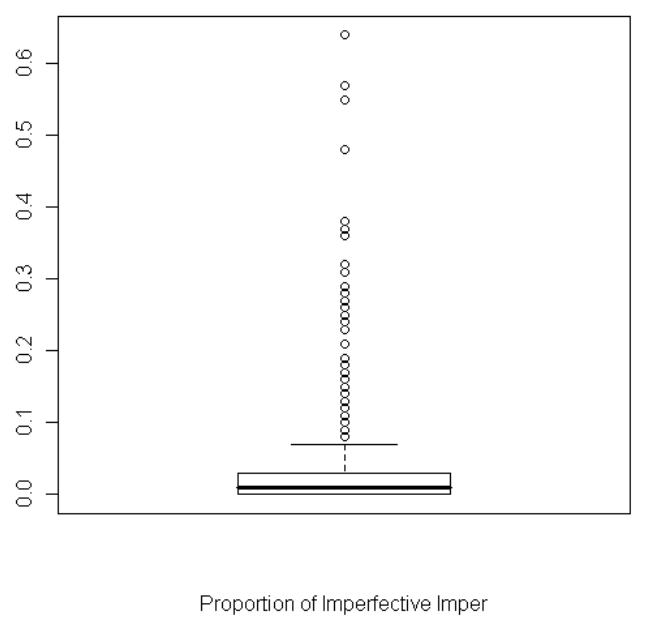

Figure 3: Distribution of imperfective imperatives

This intersection of imperfective aspect and imperative mood yields over two hundred verbs that behave as outliers because their usage exceeds 1.5 times the semiinterquartile range above the third quartile (small circles in Figure 3; the full list is found in Appendix A). While many of these verbs confirm the standard claims made in the scholarly literature, the data suggest some additional phenomena that have received less attention. Furthermore, the lexical classes that turn up among these outliers give us insights into the motives even for the expected outcomes.

In the case of politeness, our data suggest that this phenomenon is largely driven by a single frame, namely that of being a guest or visitor. Under these circumstances, the imperatives do not provide new information, but rather invite the guest to do what both the host and guest already expect to happen. This includes getting out of and into outerwear (razdevajsja(/tes') 'take off one's coat'), changing body positions (sadi(te)s' 'sit down'), joining people at the table 
(prisoedinjajsja(/tes') 'come join at the table'), consuming things (zakusyvaj(te) 'eat chasers', zakurivaj(te) 'smoke'), and traveling (zaezžaj(te) 'stop by', zalezaj(te) 'get into the car'). There are however some additional injunctions that are specifically polite, such as requests for assistance (vyručaj(te) 'help') and kind wishes (vyzdoravlivaj(te) 'get well') that cannot be motivated in Šatunovskij's model.

Many high-frequency uses of imperfective imperatives are simply familiar or even specifically rude. Familiar uses involve requests to get moving (stupaj(te) 'get going'), to focus on a new topic of conversation (gljadi(te) 'look'), and to take something that is offered (zabiraj(te) 'take'). These uses illustrate neutral affect. Rude uses have a distinctly insistent flavor, often telling the interlocutor to leave (provalivaj(te) 'get out of here') or stop doing something (končaj(te) 'stop'). However, over half of the rude uses are associated with negation, carrying the implication that the interlocutor is misbehaving, especially in discourse interactions (ne perebivaj(te) 'don't interrupt', ne prikidyvajsja(/tes') 'don't pretend to be something you aren't', ne peredergivaj(te) 'don't distort the facts'). This group is not included in Šatunovskij's analysis, which treats negation separately, stating that all imperatives are normally imperfective when negated, unless they refer to things that are hard to control and represent immediate threats. As concerns other negated imperatives in our data, these mostly represent injunctions not to be upset (ne rasstraivajsja(/tes') 'don't get upset') or not to be afraid (ne stesnjajsja(/tes') 'don't hesitate'), though a few other types appear such as ne leni(te)s' 'don't be lazy' and ne zabyvaj(te) 'don't forget'. The verbs with rude meanings also have a stronger tendency to appear in singular form (which is necessarily familiar) rather than plural (which can signal either plurality or politeness). For example otvalivaj(te) 'get out of here' has $95 \%$ of its imperative forms in the singular.

A residue of verbs appears in fixed grammatical or idiomatic expressions. The imperative of davat' 'give' is used as an auxiliary verb in forming periphrastic imperatives, as in davaj posmotrim 'let's take a look' or davajte ja vam pomogu 'let me help you'. As Barentsen (2006) points out, this expression specifically takes the interlocutor's perspective into account, yielding polite suggestions and offers, as the verbs that collocate most frequently with davaj(te) indicate: pomogu 'help', rasskažu 'tell', pokažu 'show', pozvonju 'call', sdelaju 'do'. Thus this idiomatic use of davaj(te) is also consistent with the polite use of imperfective imperatives overall. The imperative proščaj(te) functions idiomatically as a farewell greeting and is thus 
somewhat detached from the meaning of the verb 'forgive'. Three imperfective imperatives have specific cultural anchors: obogaščajsja 'be prosperous' was a buzz word of the Soviet New Economic Policy in the 1920s; soedinjajtes' 'unite' belongs to the communist slogan proletarii vsex stran soedinjajtes' 'workers of the world unite', and zapevaj 'sing' is an army command, since Russian soldiers are often required to sing in unison. Three other imperfective imperatives frequently occur in aphorisms: ne pominaj lixom 'bear no ill will [lit: don't remember evil]' and ne pominaj, kak zvali 'they just vanished [lit: don't remember, what they were called]' (together these phraes account for $76 \%$ of RNC citations); spasajsja, kto možet 'every man for himself [lit: save himself, he who can]' (42\% of RNC citations); na čužoj karavaj rot ne razevaj 'don't take others' belongings [lit: don't open your mouth at others' bread]' (53\% of RNC citations).

For comparison we sampled the non-outlier verbs in both the lowest and middle range of this distribution, and found that neither group of verbs resembles the outliers. At the bottom of the distribution are 36 imperfective, verbs with $0 \%$ frequency of imperative forms. 32 of these verbs contain the reflexive suffix -sja, and as a group they express uncontrolled actions with inanimate subjects or in impersonal constructions. Some examples (cited in their infinitive form) are vspominat'sja 'come to mind', načat'sja 'begin', and prixodit'sja 'happen'. In the middle range, with between $2 \%$ and $4 \%$ of imperative forms, we find 18 verbs that describe common actions that are not associated with politeness or urgency, such as dumat' 'think', rešat' 'solve', and smejat'sja 'laugh'.

\subsubsection{Perfective imperatives}

Relatively little has been written about perfective imperatives in the aspectual literature. The use of perfective verbs to form imperatives is predominant when the intention is to give instructions (the primary purpose of the imperative), but perfective imperatives can be rude (when used in place of polite imperfectives described in 4.2.1) or, issue warnings (Pul'kina \& Zaxava-Nekrasova 1977: 284-287, Švedova et al. 1980: 623-624, Wade 1992: 303-306). Šatunovskij (2002), after spending nearly thirty pages on the imperfective imperative, gives only a few cursory remarks on the perfective imperative (cf. also Padučeva 1996 and Timberlake 2004). 
Our hypothesis is thus that the perfective imperative should attract verbs used to deliver neutral instructions, rude demands, and warnings.

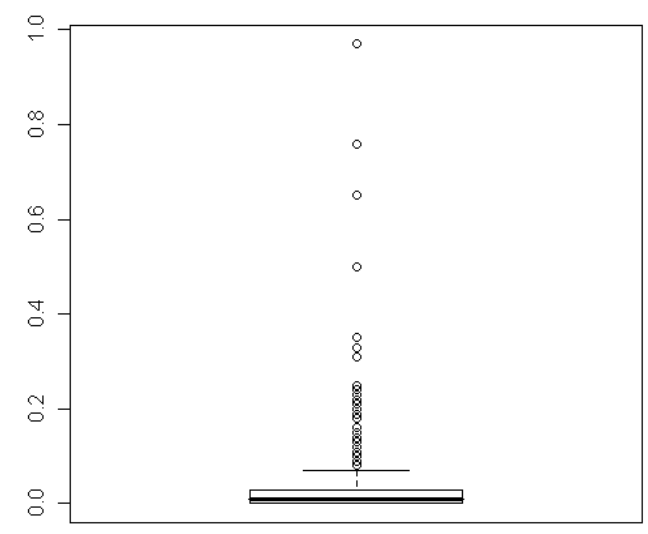

Proportion of Perfective Imper

Figure 4: Distribution of perfective imperatives

This group gives us the most skewed distribution, with over three hundred verbs acting as outliers. The entire list is presented in Appendix B. The list of verbs thus sheds new light on just exactly what kind of relationship between aspect and mood these forms represent.

As expected, two of the largest groups involve rude expressions and neutral instructions. The rude expressions are dominated by verbs used to tell someone to leave one alone (otstan'(te)) or let someone go (otpusti(te)s') or stop doing something (perestan'(te) 'stop'). Here the perfective aspect heightens the harshness of the command. The neutral instructions show evidence for a number of frames where perfective imperatives are common: cooking (vskipjati(te) 'bring to a boil'), exercising (sogni(te) 'bend'), official transactions (raspiši(te)s' 'sign for'), and text instructions (rassmotri(te) [grafik x] 'see [figure $\mathrm{x}]$ ').

Thus we confirmed the theoretical expectations about perfective imperatives concerning rude and neutral uses, but did not find a substantial number of verbs that would be used in warnings. However, we also found several other groups of perfective verbs that are often found in the imperative form. These include a fairly large group of specifically polite expressions, involving requesting forgiveness (izvini(te)), patience (poterpi(te)), and use of imagination (predstav'te)). There are also groups of verbs that are used to direct the attention of the interlocutor or to signal transitions in discourse, paralleling this phenomenon identified by Stefanowitsch \& 
Gries (2003: 233-234) among English imperatives. The attention-directing type mainly involves verbs used to ask the hearer to look at something (posmotri(te)) or listen to something (vslušaj(te)s'), though other channels of perception (ponjuxaj(te) 'sniff') and imagination (ugadaj(te) 'guess') are also invoked. The verbs used as discourse markers include items like požaluj which serves as a modal meaning 'perhaps' in this form, verbs used to take the floor like razreši(te) 'allow' (in consruction with a following infinitive), verbs used to encourage the interlocutor to speak up like podskaži(te) 'prompt, tell', and verbs signalling a request to end a topic of conversation like $u v o l$ '(te) 'spare'.

Two smaller yet important groups include religious and idiomatic expressions. Both involve formulaic expressions, which in the case of the religious expressions come from prayers and liturgical texts, as in Gospodi pomiluj 'Lord have mercy' (91\% of RNC citations are prayers or directly derived therefrom) and blagoslovi otče 'father bless' (93\% of RNC citations are of this type, with some variation in the vocative form like Gospodi 'Lord', Alla 'Allah'). Idiomatic expressions include items that occur only in specific constructions like xot' zalejsja/zavalis' meaning 'a very large amount' [lit: at least be poured/be toppled] (68\% of RNC citations), razlit' 'spill' in ne razlej voda 'really close friends' [lit: water don't spill] (90\% of RNC citations) and razodrat' 'tear up' in čert razderi 'to hell with it' [lit: devil tear] (100\% of RNC citations). Finally there is one verb, dat' 'give' that is used as an auxiliary verb in a specific construction where many perfective verbs can appear, as in $d a j$ posmotrju 'let me take a look' [lit: give I will look]. Barentsen (2006) shows that the vebs that collocate most frequently with this construction indicate that the speaker is motivated by his/her own desires (rather than the addressee's): poceluju 'kiss', posmotrju 'take a look', pogljažu 'take a look', vzgljanu 'take a look'. These expressions are not directly rude; they minimize consideration for the interlocutor's perspective and are thus neutral.

At the bottom of the distribution, 13 perfective verbs with $0 \%-1 \%$ imperative forms are all associated with the so-called "quasi-imperative" construction which describes sudden events rather than human actions, as in example 1.

\section{1) Načnis' sxvatka -- ee by ubili.}

'If a fight were to break out, she would be killed.' 
These "bottom-dweller" verbs represent a clear departure from the outlier verbs. However, the 8 verbs in the middle range (3.8\%-5.2\%) represent typical neutral instructions such as poprosi(te) 'ask', pokaži(te) 'show', and prinesi(te) 'bring', and thus overlap with the outlier group in this use.

\subsubsection{Imperfective non-past}

Grammars of Russian consistently characterize the imperfective non-past as used primarily for description of ongoing processes, concrete processes that have a duration and/or are simultaneous with another time or event, and repeated actions (Pul'kina \& Zaxava-Nekrasova 1977: 264-270, Švedova et al. 1980: 604, Wade 1992: 283-286). The use of the imperfective non-past to describe timeless facts (gnomic) ${ }^{15}$ or historical present is mentioned only secondarily. Given this pattern, we hypothesize that the positive outliers for this paradigm slot should be dominated by verbs describing ongoing, durative, and simultaneous actions. However, this hypothesis was not confirmed.

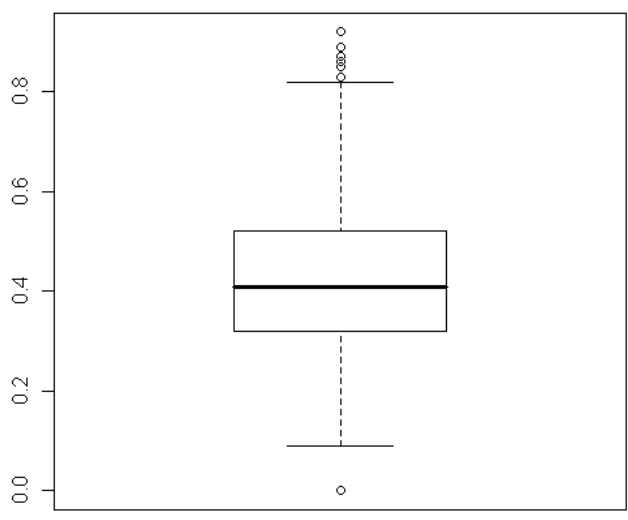

Proportion of Imperfective NonPast

Figure 5: Distribution of imperfective non-past

Figure 5 shows that there are some imperfective verbs with an unusually high proportion of forms in the non-past subparadigm, and one verb with an unusually low proportion of forms in this subparadigm. Table 4 lists these verbs and their frequencies.

\begin{tabular}{|l|l|l|l|}
\hline verb $(3 \mathrm{sg})$ & gloss & raw freq & $\%$ freq \\
\hline
\end{tabular}

\footnotetext{
${ }^{15}$ For a discussion of gnomic uses of imperfective aspect, see Janda 2004.
} 


\begin{tabular}{|l|l|r|r|}
\hline javljat'sja (javljaetsja) & 'be' & 39543 & $92 \%$ \\
\hline okazyvat'sja (okazyvaetsja) & 'turn out to be' & 10869 & $85 \%$ \\
\hline podtverždat'sja (podtverždaetsja) & 'be confirmed' & 677 & $83 \%$ \\
\hline vyjasnjat'sja (vyjasnjaetsja) & 'be explained' & 805 & $89 \%$ \\
\hline kasat'sja (kasaetsja) & 'concern' & 9719 & $87 \%$ \\
\hline isčerpyvat' (isčerpyvaet) & 'exhaust' & 100 & $89 \%$ \\
\hline predopredeljat'sja (predopredeljaetsja) & 'be predetermined' & 34 & $85 \%$ \\
\hline objazyvat'sja (objazyvaetsja) & 'be obliged to' & 480 & $92 \%$ \\
\hline zatrudnjat'sja (zatrudnjaetsja) & 'be made difficult' & 275 & $86 \%$ \\
\hline vleč' (vlečet) & 'entail' & 1555 & $85 \%$ \\
\hline slyxat' (slyxaet) & 'hear' & 1 & $0 \%$ \\
\hline
\end{tabular}

Table 4: Imperfective verbs with very high or low incidence of non-past forms

The ten imperfective verbs with unusually high representation in non-past forms all instantiate a single phenomenon that is expressed in Russian exclusively via the combination of imperfective aspect and non-past tense. This is the gnomic construction, which describes timeless truths. Examples 2 and 3 illustrate the gnomic use of such verbs.

(2) Drugimi slovami, ja by xotel sprovocirovat' diskussiju, to vsegda javljaetsja naibolee produktivnoj formoj naučnogo obsuždenija problemy.

'In other words, I would like to provoke a discussion, which is always the most productive form for scholarly debate on an issue.'

(3) Kak pravilo, dannoe obstojatel'stvo vlečet za soboj negativnye posledstvija dlja klientov.

'As a rule, this situation entails [lit: $\underline{\text { drags }}$ after itself] negative consequences for the clients.'

The verb javljaetsja 'is' can only be used to identify the category that something is classified in; here, a discussion is classified as the most productive form for scholarly debate. The first six verbs in Table 4 are all variants on gnomic statements like this that claim ' $\mathrm{X}$ is $\mathrm{Y}$ '. The remaining four verbs with high frequency in the imperfective non-past have the meaning ' $\mathrm{X}$ causes/entails $\mathrm{Y}$ ', as illustrated by example 3 .

These verbs can also be organized according to their conventional uses. Three of the verbs appear in fixed constructions: okazyvaetsja 'turns out to be' (95\% of citations in RNC); vyjasnjaetsja, (čto)/kak vyjasnjaetsja 'turns out that/as it turns out' ( $87 \%$ of citations in RNC); and čto kasaetsja X 'as far as X is concerned' (68\% of citations in RNC). Two of the verbs are prominent in certain contexts. A stock phrase of mediated negotiations is storony/partii objazujutsja/predstavitel' objazuetsja 'the parties are obliged to/the representative is obliged to' (75\% of citations in RNC). 
When opinion polls are conducted, one of the standard choices is zatrudnjajus' otvetit' 'not sure' [lit. I have difficulty answering] (27\% of citations in RNC).

The one verb that is an outlier at the bottom end of the scale, with only one non-past form, slyxat' 'hear', is a morphological anomaly. This verb simply does not have non-past forms. This anomaly is motivated by the fact that this verb has the evidential function of reporting hearsay, which is connected with the past tense (cf. 4.2.7 where this verb appears as an outlier on the top end of the scale for imperfective past tense forms). The neutral verb for 'hear' is slyšat'.

Neither the low end nor the mid-range of this distribution presents verbs that are associated with gnomic uses. At the low end (under 20\% imperfective non-past forms) we find verbs like obedat' 'eat lunch' and golosovat' 'vote', while in the middle we find verbs like rabotat' 'work' and pomogat' 'help'.

\subsubsection{Perfective non-past}

The perfective non-past is the morphological form used to express simple future in Russian and is associated with concrete single actions expected to be completed in the future, though more rarely it can be used to describe habitually repeated actions (usually ones belonging to a sequence) and exemplary actions (Pul'kina \& ZaxavaNekrasova 1977: 264-270, Švedova et al. 1980: 604, Wade 1992: 283-286). Our hypothesis is correspondingly that the verbs at the top of the distribution should reflect description of predicted or promised actions, and that hypothesis is confirmed.

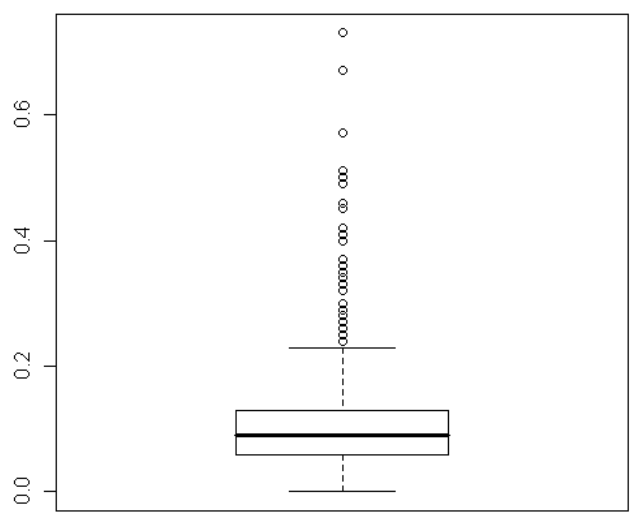

Proportion of Perfective NonPast 
Eighty-four perfective verbs, listed in Appendix C, qualify as outliers due to their unusually strong representation in the non-past subparadigm. These verbs reflect the default interpretation of perfective non-past as referring to the future, since most of them are used in expressing predictions and promises. Predictions can be parametric, involving increasing (prevysit 'will exceed'), decreasing (umen 'šitsja 'will decrease') and length of continuation (prodlitsja 'will last'). Predictions also often target expected improvements (naladitsja 'will work out well', vyzdoroveet 'will get well'), problems (zatrudnit 'will make things difficult', razoritsja 'will go broke') and needs (potrebuetsja 'will be necessary'). A problem that is often predicted is death; five verbs such as podoxnet and zagnetsja, both meaning 'will die', are used to announce impending mortality. Closely related to verbs signalling needs are two verbs that appear in impersonal modal constructions: pridetsja 'will be necessary' and (ne) obojdetsja (bez) 'will (not) manage (without)'. Promises are a specialized kind of prediction, as in upravitsja 'will take care of something' and postaraetsja 'will try'. Threats are in a sense negative promises, and this group includes items like rasterzaet 'will tear to pieces' and prokljanet 'will curse'. Many of the verbs involving death or threats are also metaphorical or metonymic: sožret is literally 'will eat up', but is parallel to the English expression will eat $X$ alive, which is a warning of various kinds of danger, but usually does not refer to beasts devouring people; sgniet 'will rot' refers to death via the prediction of what happens afterward. Also related to promises are verbs used as performatives in discourse, usually in first person singular forms such as osmeljus' 'I (will) dare, I (will) take the liberty of' or procitiruju 'I (will) quote'. Several of the verbs are found among the outliers for this subparadigm because they occur in fixed expressions: ne priderešsja 'don't find fault with' (98\% of RNC citations), ostal'noe priložitsja 'the rest will come' (74\% of RNC citations), ot tebja ne ubudet 'nothing is going to happen to you' (96\% of RNC citations), vragu ne poželaeš' 'I wouldn't wish it on my worst enemy' (with slight variations, 65\% of RNC citations). Finally there is a residue of verbs with lexical meanings that don't seem to fit into any of the above-mentioned groups, such as: vysoxnet 'will dry out', poletit 'will fly/take off'.

At the bottom end of this distribution (0\%-1\%) we find two types of verbs that describe actions which are not usually predictable: manner-of-speech verbs like probormočet 'will mumble' and vzvizgnet 'will squeal' and verbs of interpretation (Apresjan 2004) like izvinit 'will apologize' and nedoocenit 'will underestimate'. The 
mid-range (12\%-15.35\%) is a homogenous group that is not particularly associated with predictions, promises or performatives, with verbs like uslyšit 'will hear', pokažet 'will show' and pošlet 'will send'.

\subsubsection{Imperfective infinitive}

In addition to its use in the periphrastic imperfective future and after phasal verbs, the imperfective infinitive is associated with modal expressions (Pul'kina \& ZaxavaNekrasova 1977: 272-275, Wade 1992: 307-312). Contrary to typological trends, the default aspect for modal expressions in Russian is perfective, although imperfective is also common (cf. Divjak 2009 for a comparison of Russian with usual typological observations). Šmelev \& Zaliznjak (2006) point out that in such modal constructions the perfective aspect describes "alethic" (also known as "dynamic") modality, in other words physical necessity or possibility, whereas the imperfective expresses deontic modality, in other words social or moral desirability. Šmelev \& Zaliznjak claim that this difference is accounted for by controllability, namely that perfectives are used in contexts where the event is out of the subject's control, whereas imperfectives are used when the subject is in control. This introspective analysis seems to work for the minimal-pair-type examples that Šmelev \& Zaliznjak offer, such as Nel'zja razbudit' otca 'It is impossible to wake father' (he physically cannot be wakened) vs. Nel'zja budit' otca 'Don't wake father' (it is the wrong thing to do). In a quantitative analysis, Divjak (2009) shows that it is not controllability, but rather specificity that predicts the aspect of infinitives in such constructions. In other words, because the Russian perfective aspect is associated with specific situations, it favors interpretations in terms of individual capacity. The imperfective aspect is associated instead with generic situations (like the gnomic uses discussed in 4.2.3), and this favors an interpretation in terms of overall norms of responsibility and desirability, as illustrated in example 3. Divjak coded a database of corpus examples according to various factors and fitted a mixed effects logistic regression model to the data to predict aspect. She found that the one factor that was crucial was specificity: in modal expressions, imperfective infinitives describe non-specific events, whereas perfective infinitives are used with specific events. 
As it turns out, all of the outlier verbs in this distribution reflect use of modal expressions, for which we accordingly have two hypotheses. The first hypothesis tests Šmelev \& Zaliznjak's (2006) claim, which would predict imperfective infinitives that express controllable actions. The second hypothesis tests Divjak's (2009) claim, which would predict imperfective infinitives used to describe non-specific actions.

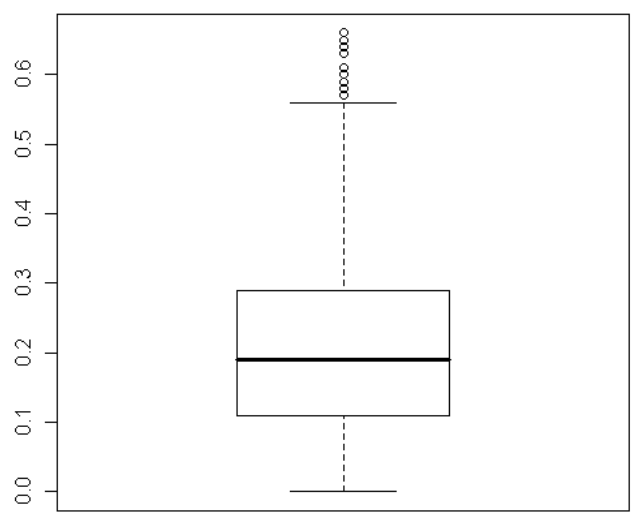

Proportion of Imperfective Inf

\begin{tabular}{|l|l|r|r|}
\hline verb & gloss & raw freq & $\%$ freq \\
\hline plevat' & 'spit' & 900 & $65 \%$ \\
\hline vvjazyvat'sja & 'get mixed up in' & 124 & $66 \%$ \\
\hline izyskivat' & 'search out, try to find' & 92 & $64 \%$ \\
\hline ispravljat' & 'repair, carry out' & 283 & $61 \%$ \\
\hline peredelyvat' & 'redo, alter' & 230 & $57 \%$ \\
\hline peresmatrivat' & 'revise, reconsider' & 198 & $66 \%$ \\
\hline razvivat' & 'develop' & 1363 & $57 \%$ \\
\hline razmeščat' & 'place, distribute' & 272 & $58 \%$ \\
\hline raspoznavat' & 'recognize, identify' & 113 & $59 \%$ \\
\hline sobljudat' & 'observe, conform to' & 1013 & $60 \%$ \\
\hline soglasovyvat' & 'conform to, agree with' & 1850 & $63 \%$ \\
\hline učityvat' & 'take into account, bear in mind' & $66 \%$ \\
\hline
\end{tabular}

Table 5: Imperfective verbs with very high incidence of infinitive forms

Twelve imperfective verbs, listed in Table 5, have an unusually high proportion of infinitive forms. The first verb in the table appears to be motivated by a fixed construction, namely mne plevat' 'I don't give a damn' [lit: I (feel like) spitting] (90\% of citations in RNC). The remaining verbs are associated with modal constructions that consist of an infinitive in conjunction with a modal word like the following: nado 'have (to)', nužno 'need (to)', dolžen 'supposed (to)', možno 'can/is possible (to)', 
nel'zja 'not possible/not allowed (to)', prixoditsja/pridetsja 'is/will be necessary (to)', sleduet 'ought, should'.

Our study provides new data that supports Divjak's (2009) analysis. The eleven verbs in Table 4 that are used in modal expressions do not all express actions that are necessarily controllable; vvjazyvat'sja 'get mixed up in', raspoznavat' 'recognize, identify', and soglasovyvat' 'conform to, agree with' can all describe actions beyond the subject's conscious control. Divjak's (2009) hypothesis that imperfective infinitives are used in expressions of circumstances because they refer to generic obligations and possibilities is supported by the lexical meanings of our eleven verbs. These verbs target actions such as abiding by rules (sobljudat' 'observe, conform to'), revising and repairing things (peredelyvat' 'redo', ispravljat' 'repair') and in general trying to behave properly and make things better (učityvat' 'take into account'). In addition one of the verbs in our list for imperfective infinitives is paired with a verb that also appears on the list in the following subsection of perfective infinitives: sobljudat'[i] vs. sobljusti[p] 'observe, conform to'. Examples comparing the use of these two infinitives in modal constructions appear in 4 and 5.

4) Po-moemu esli ty dejstvitel'no verujuščij čelovek, to konečno nado sobljudat'[i], kak velit cerkov'.

'In my opinion if you really are a religious person, then of course you need to conform to what the church commands.'

5) Edinstvennoe pravilo, kotoroe vy pri ètom dolžny sobljusti[p]: stil' vašej odeždy dolžen byt' identičen obščemu stilju, prinjatomu na firme.

'The only rule that you need to observe in this situation is this: the style of your clothing must be identical to the overall style that is customary at the firm.'

The appearance of both of these verbs as high-frequency items in modal constructions is important because this verb pair is lexically restricted to reference to circumstances: neither the imperfective nor the perfective can express physical necessity or capacity. Futhermore, neither of these verbs can express a noncontrollable situation since observance of rules and norms can occur only through conscious effort, not by accident. Yet still we see an aspectual difference in modal constructions, and that difference conforms to Divjak's (2009) findings. Example 4 describes a generalized rule for all behavior lacking any specific context, and this is where we find the imperfective. Example 5, with the corresponding perfective, 
describes the choice of clothing (skirt vs. slacks) for a professional woman in a very specific business situation.

Comparison of the top, middle and bottom portions of this distribution shows that each is associated with a certain type of verb. The outliers at the top, as we have seen, are used in modal expressions. In the middle (16.4\%-20\%) we find verbs that are typically used in the periphrastic future, like (budet) demonstrirovat' 'will demonstrate' and (budet) privetstvovat' 'will welcome'. At the bottom of the distribution we find verbs that don't work well in either type of construction, such as uxitrjat'sja 'contrive' and perepolnjat' 'overfill'.

\subsubsection{Perfective infinitive}

The perfective infinitive is subject to the converse of the same hypotheses stated for the imperfective infinitive in 4.2.5. The first hypothesis follows Šmelev \& Zaliznjak 2006, according to which we expect a high incidence of verbs expressing noncontrollable actions, and the second hypothesis follows Divjak 2009, expecting a high incidence of specific actions.

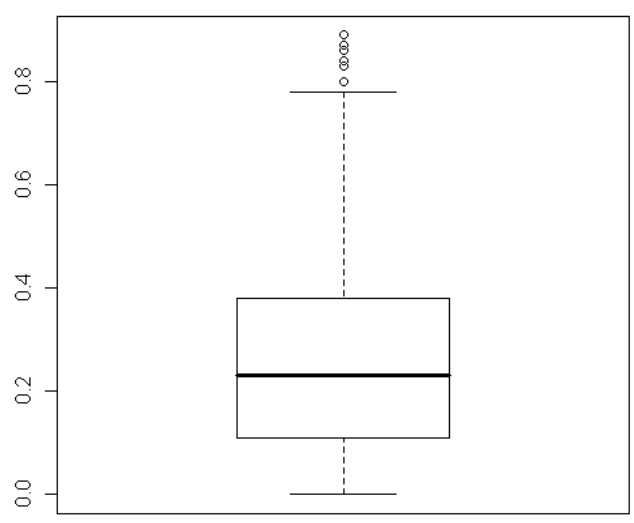

Proportion of Perfective Inf

\begin{tabular}{|l|l|r|r|}
\hline verb & gloss & raw freq & $\%$ freq \\
\hline naplevat' & 'spit' & 860 & $89 \%$ \\
\hline sovmestit' & 'combine' & 385 & $87 \%$ \\
\hline predotvratit' & 'prevent' & 792 & $86 \%$ \\
\hline vossozdat' & 'reconstruct' & 248 & $84 \%$ \\
\hline pomyslit' & 'contemplate' & 129 & $84 \%$ \\
\hline sobljusti & 'observe, conform to' & 200 & $84 \%$ \\
\hline sootnesti & 'correlate' & 118 & $84 \%$ \\
\hline
\end{tabular}




\begin{tabular}{|l|l|r|r|}
\hline vozmestit' & 'compensate' & 304 & $83 \%$ \\
\hline vospolnit' & 'fill in' & 171 & $80 \%$ \\
\hline podrabotat' & 'earn additionally, work up' & 91 & $80 \%$ \\
\hline srazit'sja & 'fight, join in battle with' & 108 & $80 \%$ \\
\hline ustranit' & 'remove' & 686 & $80 \%$ \\
\hline
\end{tabular}

Table 6: Perfective verbs with very high incidence of infinitive forms

In some ways this group parallels the verbs that show high incidence of imperfective infinitives. The verb naplevat' $[\mathrm{p}]$ 'spit' is the paired aspectual correlate of the imperfective plevat' [i] and its presence is motivated by the same fixed phrase (which can appear in both aspects): mne naplevat' 'I don't give a damn' (100\% of citations in RNC). The remaining verbs can all combine with modals, in which case the perfectives refer to specific situations as opposed to the imperfectives (cf. the comparison of examples 3 and 4 above). However, these perfective infinitives are associated with some additional constructions, all of which favor the perfective aspect. These constructions, illustrated in examples 6,7 , and 8 with the verb vospolnit' 'fill in', involve the so-called 'tentative" verbs (meaning trying, wanting, etc.), čtoby 'in order to [achieve $\mathrm{X}$ ]' and various adverbs describing how important or difficult it is to achieve $\mathrm{X}$.

6) Poètomu my popytaemsja vospolnit' ètot probel, opirajas' na fakty i cifry, privedennye $v$ rabotax sovremennyx istorikov.

'That is why we are going to try to fill in that gap by relying on the facts and figures cited in the works of contemporary historians.'

7) Posle zanjatija možno vypit' vody, čtoby vospolnit' ee poterju.

'After working one can drink some water in order to make up for its loss.'

8) Fruktami istinnyj deficit kalija vospolnit' očen' tjaželo, praktičeski nevozmožno. 'It is very difficult, practically impossible, to make up for a real calcium deficiency by [eating] fruit.'

Divjak (2004: 256) shows that tentative verbs strongly favor the use of perfective infinitives in examples like 6 . The constructions in examples 7 and 8 both describe achievements, so the choice of the perfective is natural.

Both the low (0\%-0.5\%) and middle (20\%-23\%) part of this distribution is inhabited by verbs that express changes of state that are not particularly associated with modal expressions, such as (bottom:) poser'eznet' 'become serious' and posinet' 'turn blue', and (middle:) lišit'sja 'lose' and otkryt' 'open.' 


\subsubsection{Imperfective Past}

According to grammars of Russian, the imperfective past is used primarily to describe durative or repeated actions in the past. This form can additionally express statements of fact, attempted actions, and annulled actions, though these uses are secondary (Pul'kina \& Zaxava-Nekrasova 1977: 278, Švedova et al. 1980: 604-611, Wade 1992: 289-293). We thus hypothesize that the outliers will be dominated by verbs that express past actions that are either durative or repeated.

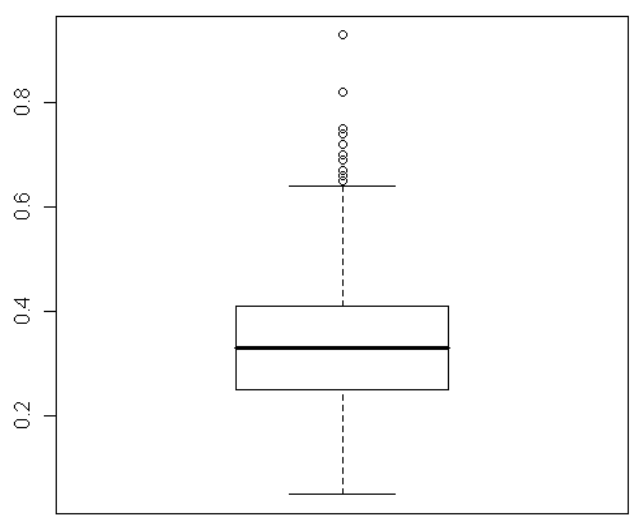

Proportion of Imperfective Past

\begin{tabular}{|l|l|r|r|}
\hline verb & gloss & raw freq & $\%$ freq \\
\hline slyxat' (slyxal) & 'hear' & 1161 & $93 \%$ \\
\hline slyt' (slyl) & 'have a reputation for' & 212 & $72 \%$ \\
\hline prosiživat' (prosižival) & 'sit up repeatedly' & 123 & $67 \%$ \\
\hline proxaživat'sja (proxaživalsja) & 'go for strolls' & 207 & $69 \%$ \\
\hline belet' (belel) & 'show white' & 366 & $70 \%$ \\
\hline mračnet' (mračnel) & 'show dark, glower' & 99 & $75 \%$ \\
\hline černet' (černel) & 'show black' & 348 & $75 \%$ \\
\hline svešivat'sja (svešivalsja) & 'hang, dangle' & 105 & $74 \%$ \\
\hline nadvigat'sja (nadvigalsja) & 'be approaching' & 260 & $66 \%$ \\
\hline pomyšljat' (pomyšljal) & 'think, dream of' & 189 & $69 \%$ \\
\hline unimat'sja (unimalsja) & 'be stoppable' & 381 & $82 \%$ \\
\hline ščurit'sja (ščurilsja) & 'squint' & 196 & $67 \%$ \\
\hline otšučivat'sja (otšučivalsja) & 'make joking replies' & 80 & $74 \%$ \\
\hline
\end{tabular}

Table 7: Imperfective verbs with very high incidence of past tense forms

A variety of morphological, lexical and constructional factors contribute to the behavior of the outliers representing the imperfective past tense. The verb with by far 
the highest relative frequency in this group is slyxal 'heard', which, as we saw in section 4.2.3, lacks non-past forms. Its use is largely restricted to the past and infinitive due to its morphologically defective paradigm. Furthermore, both slyxal 'heard' and slyl 'had the reputation of being' serve as evidentials, which are typologically associated with the past tense (Aikhenvald 2003).

Most of the verbs on this list probably have larger-than-normal frequency in the past subparadigm partly because they lack imperative forms altogether. This includes prosižival 'sat up repeatedly', proxaživalsja 'went for strolls', belel 'showed white', černel 'showed black', slyxal 'heard', slyl 'had the reputation of being', ne unimalsja 'was unstoppable', nadvigalsja 'was approaching', mračnel 'showed dark, glowered', svešivalsja 'hung, dangled'.

Two of these verbs are habituals: prosižival 'sat up repeatedly' and proxaživalsja 'went for strolls'. Habituals are by definition imperfective and tend to be in the past because they require observation over a number of often discontinuous events. Danaher 2003 reports that habituals are strongly associated with the past tense in Russian.

Narration of observations motivate several verbs. Three verbs (belel 'showed white', černel 'showed black', and mračnel 'showed dark') are used to report the visibility of objects that appear either dark or bright to an observer. One verb describes an observed posture: svešivalsja 'hung, dangled', which is restricted in the kinds of subjects it can take to items like bel'e '(just washed) clothing' and nogi 'legs'. A further verb is used to report meteorological observations, as in groza nadvigalas' 'a storm was aproaching'. The reporting of such observations is typically given in the past tense, and since these verbs describe characteristics rather than unique events, imperfective is the appropriate aspect.

Two verbs, (ne) pomyšljal '(not) thought about, dreamt of' and (ne) unimalsja 'there was no stopping $\mathrm{X}$ ' are strongly associated with the use of negation to make categorical statements. These verbs instantiate the acknowledged relationship between negation and imperfective aspect (cf. Janda 2004 and references therein). Past tense is prioritized because these verbs describe an expectation that was not fulfilled over a period of time.

Finally there are some extended behaviors that are observed in the course of accompanying dialog: ščurilsja 'squinted', otšučivalsja 'made joking replies', mračnel 'glowered'. 
At the bottom of this distribution (below 10\%) we find verbs that are either gnomics (as in 4.2.3) like javljalsja 'was' and kasalsja 'concerned' or are found mostly in the imperative form like proščalsja 'was saying farewell'.

\subsubsection{Perfective past}

Despite its high overall frequency, the scholarly literature has little to say about the perfective past other than that it is used to describe single completed events (Pul'kina \& Zaxava-Nekrasova 1977: 279, Švedova et al. 1980: 604, Wade 1992: 289). It is hard on this basis to construct much in the way of a specific hypothesis.

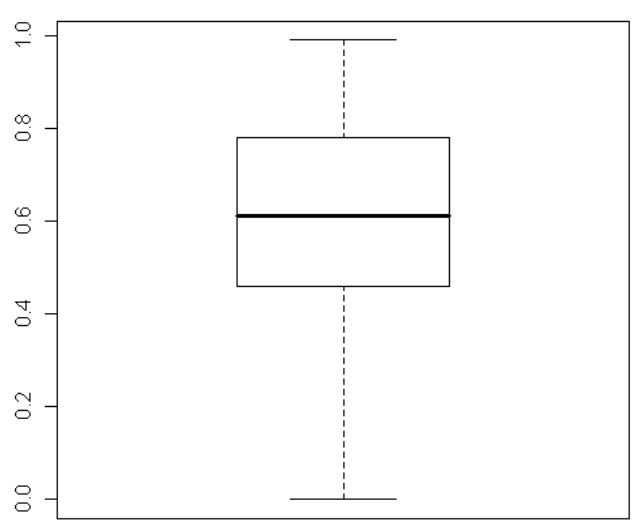

Proportion of Perfective Past

For this group, the median and variance are such that \pm 1.5 times the interquartile range covers the entire spectrum of possibilities, from $0 \%$ to $100 \%$, so there are no outliers.

\subsection{Conclusions}

One challenge for linguistic analysis of corpus data is calibration of the level of granularity. It is technically possible to collect data at a very fine-grained level, but that level may not be the one that is most propitious since it may include factors that are not relevant for the object of study. At the other extreme, the lemma level might collapse too much information, obscuring important structure in the data. Decisions about granularity need to take into account both the linguistic object of study and specific facts about the language in question. Languages vary greatly in terms of the complexity of their morphologies, as well as to what extent various linguistic 
categories interact with those morphologies. It is necessary to target precisely the level of granularity at which the interaction between linguistic category and morphology (or other formal structure) is most concentrated.

The findings in this article argue for the subparadigm as the appropriate level of granularity for corpus data on TAM categories in Russian. The subparadigm is the level at which the major verbal categories are realized (tense, finiteness, voice). This level also eliminates categories that are presumably not relevant to TAM, such as person, number, gender, and case. The subparadigm gives us valuable insights into both the overall behavior of aspect and the lexical classes that are most driven by the interaction of aspect with tense and mood.

A database of nearly six million uses of forms representing verb pairs derived via prefixation (p-partners) as opposed to suffixation (s-partners) sheds new light on a long-standing debate in Russian linguistics. According to the traditional hypothesis both types of derivation lead to aspectual pairs, whereas according to the Isačenko hypothesis aspectual pairs are created only via suffixation. Our data finds no appreciable difference in the behavior of the two kinds of partners, thus supporting the traditional hypothesis. Given these findings, it makes sense to ask why Isačenko suggested that there should be a difference between $\mathrm{p}$ - and s-partners in the first place. The reason is that Isačenko (1960: 130-175) was opposed to the traditional claim that the prefixes in the p-partners were semantically "empty". Isačenko made his protests with good reason, insisting that the prefixes must contribute meaning since the same prefixes are uncontroversially non-empty in the formation of Specialized and Complex Act Perfectives. Thus Isačenko reasoned that the p-partner relationship was not "purely aspectual" since it involved a lexical contribution from the prefix. However, there is a third logical possibility that can reconcile the traditional hypothesis with the Isačenko hypothesis, namely that the prefix, while retaining its lexical meaning, overlaps in meaning with the base verb to the extent that its meaning does not significantly change the meaning of the prefixed verb beyond signalling perfectivity. This third option, originally proposed by Vey (1952) and van Schooneveld (1958) has received new empirical support from Janda and Nesset (2010), and is also compatible with our findings.

The possibility that the meanings of the prefix and verb overlap and are thus co-selected also finds support from corpus studies of lexical semantics. The prefixverb combination in a p-partner relationship can be likened to a collocation. As 
Stubbs (2001: 63) points out, collocations often invove forms that "share" semantic features, as in English phrases such as physical assault, where the adjective physical "adds little to the meanings of the noun, but merely emphasizes or focuses on an expected feature". Stubbs laments that linguists seem to lack a standard term for this phenomenon, which is often referred to as "bleaching" or "elimination", terms that are parallel to the traditional use of the term "empty prefix" (pustaja pristavka) in Russian linguistics.

The database of verb forms was probed for outliers: lexical items that exceeded \pm 1.5 times the interquartile range in their representation in the various subparadigms. The findings here are highly relevant to ongoing debates on the interrelations of lexical meaning with tense, mood, and aspect in Russian. Our data support some scholarship in this area, challenge other works, and suggest some new areas for further research.

Outliers among imperfective imperatives confirm Šatunovskij’s $(2002,2009)$ introspective analysis, but also extend the list of polite injunctions for "scripted" behaviors that typify this intersection of mood and aspect to include requests for assistance and kind wishes. The examples of rude forms give new evidence of what kinds of actions are included here. Additionally we find a group of imperfective imperatives that are neither polite nor rude, but simply familiar. This latter group has not been the subject of previous research. Perfective imperatives present a similarly large and revealing group of outlier verbs. Whereas previous research has focused on rude and neutral uses, we can detail which contexts call for neutral perfective imperatives, and we also find that there are some uses that are specifically polite. In addition, we find a parallel to English (Stefanowitsch \& Gries 2003) in the use of imperatives for attention-directing.

The main driving force for outliers among imperfective non-past forms is apparently gnomic reference, which is a bit surprising given the fact that the ongoingdurative meaning of the imperfective is usually considered the most prototypical use. Perfective non-past forms appear to be motivated by various kinds of predictions, among them predictions of improvements and problems, as well as threats and promises. In discourse the perfective non-past also serves a performative function.

Due to the lack of modal verbs in Russian (cf. Divjak 2004), modal expressions rely on a variety of constructions containing infinitives, which can be either imperfective or perfective. Scholars have presented different proposals 
concerning the role of aspect in such constructions, but our data supports the hypothesis that imperfective infinitives are used primarily for expressing generic circumstances, as opposed to perfective infinitives which are used for specific situations, where they can express either circumstances or physical necessity/capacity. Perfective infinitives participate in a number of other constructions, including those containing tentative verbs and adverbs describing the diffculty or importance of an achievement.

Only imperfective verbs surface as outliers in the past subparadigm, and these are associated with evidentials, habituals and the narration of observations.

All outlier groups exhibit some lexical items that are strongly metaphorical and/or appear in fixed idiomatic phrases, and many of these items are strongly associated with certain discourse situations.

These results are valuable both for their linguistic insights and for their potential in language teaching, where instruction can be tailored to target the forms given verbs are most likely to appear in.

\section{Works Cited}

Aikhenvald, Alexandra Y. 2003. Evidentiality in typological perspective. In A. Y. Aikhenvald \& R. M. W. Dixon (eds.), Studies in evidentiality. Typological studies in language (Vol. 54), 33-62. Amsterdam: John Benjamins Publishing Company.

Apresjan, Jurij D. 2004. Interpretaciionnye glagoly. Russkij jazyk v naučnom osveščenii 7. 5-22.

Baayen, Harald. 2008. Analyzing Linguistic Data. Cambridge: Cambridge University Press.

Barentsen, Adrian. 2006. K voprosu o vidovoj opozicii v konsrukcijax tipa daj pomogu - davaj pomogu. In: Volkma Lehmann (ed.), Glagol'nyj vid i leksikografija, 37-66. Munich: Otto Sagner.

Binnick, Robert I. 1991. Time and the Verb. Oxford: Oxford University Press.

Bondarko, Aleksandr V. 1983. Principy funkcional'noj grammatiki i voprosy aspektologii. Leningrad: Nauka.

Bondarko, Aleksandr V., Lev L. Bulanin. 1967. Russkij glagol. Leningrad: Prosveščenie. 
Bybee, Joan L., Revere Perkins, and William Pagliuca. 1994. The Evolution of Grammar: Tense, Aspect, and Modality in the Languages of the World. University of Chicago Press.

Čertkova, Marina Ju. 1996. Grammatičeskaja kategorija vida v sovremennom russkom jazyke. Moscow: Moscow State University.

Chung, Sandra and Alan Timberlake. 1985. Tense, aspect, and mood. In Timothy Shopen (ed.), Language typology and syntactic description, Volume III: Grammatical categories and the lexicon, 202-258. Cambridge: Cambridge University Press.

Cohen, Jacob. 1988. Statistical Power Analysis for the Behavioral Sciences. Mahwah, New Jersey/London: Lawrence Earlbaum Associates.

Cohen, Jacob, Patricia Cohen, Stephen G. West and Leona S. Aiken. 2003. Applied Multiple Regression/Correlation Analysis for the Behavioral Sciences. Mahwah, New Jersey/London: Lawrence Earlbaum Associates.

Comrie, Bernard. 1976. Aspect. Cambridge: Cambridge University Press.

Cubberly, Paul V. 1982. On the 'empty' prefixes in Russian. Russian Language Journal 36. 14-30.

Danaher, David. 2003. The Semantics and Discourse Function of Habitual-Iterative Verbs in Contemporary Czech. Munich: Lincom Europa.

Dickey, Stephen. 2000. The Parameters of Slavic Aspect. Stanford: CSLI Publications.

Dickey, Stephen M. and Laura A. Janda. 2009. Xoxotnul, sxitril: The relationship between semelfactives formed with -nu- and $s$ - in Russian. Russian Linguistics 33. 229-248.

Divjak, Dagmar. 2004. Degrees of Verb Integration: Conceptualizing and Categorizing Events in Russian. PhD Dissertation, KU Leuven.

Divjak, Dagmar. 2009. Mapping between domains. The aspect-modality interaction in Russian. Russian Linguistics 33. 249-269.

Divjak, Dagmar and Stefan Th. Gries. 2006. Ways of trying in Russian: Clustering behavioral profiles. Corpus Linguistics and Linguistic Theory 2. 23-60.

Evgen'eva, A. P., ed. 1999. Malyj Akademičeskij Slovar'. Moscow: Russkij jazyk.

Gries, Stefan Th. Forthcoming. Corpus data in usage-based linguistics: What's the right degree of granularity for the analysis of argument structure constructions? In Brdar, Mario, Milena Žic Fuchs, and Stefan Th. Gries (eds.), Expanding cognitive linguistic horizons. Amsterdam, Philadelphia: John Benjamins. 
Gries, Stefan Th. and Dagmar S. Divjak. 2009. Behavioral profiles: a corpus-based approach towards cognitive semantic analysis. In Vyvyan Evans \& Stephanie S. Pourcel (eds.), New directions in cognitive linguistics, 57-75. Amsterdam: John Benjamins.

Isačenko, A. V. 1960. Grammatičeskij stroj russkogo jazyka v sopostavlenii s slovackim - Čast'vtoraja: morfologija. Bratislava: Izdatel'stvo akademii nauk.

Janda, Laura A. 2004. A metaphor in search of a source domain: the categories of Slavic aspect. Cognitive Linguistics 15. 471-527.

Janda, Laura A. 2007. Aspectual clusters of Russian verbs. Studies in Language 31. 607-648.

Janda, Laura A. 2010. Prefixed Perfectives from Non-Determined Motion Verbs in Russian. In Viktoria Driagina-Hasko and Renee Perelmutter (eds.), New Approaches to Slavic verbs of motion (= Studies in Language Companion Series 115), 125-140. Amsterdam/Philadelphia: John Benjamins.

Janda, Laura A. and Tore Nesset. 2010. Taking Apart Russian RAZ-. Slavic and East European Journal 54(3). 476-501.

King, Bruce M and Edward Minium. 2008. Statistical Reasoning in the Behavioral Sciences. Hoboken, NJ: John Wiley \& Sons.

Krongauz, Maksim A. 1998. Pristavki i glagoly v russkom jazyke: semantičeskaja grammatika. Moscow: Jazyki russkoj kul’tury.

Lyashevskaya, O. N. and S. A. Sharoff. 2010. Častotnyj slovar' sovremennogo russkogo jazyka (na materiale Nacional'nogo korpusa russkogo jazyka). Moscow: Azbukovnik.

Makarova, Anastasia and Laura A. Janda. 2009. Do It Once: A Case Study of the Russian - yy-Semelfactives. Scando-Slavica 55. 78-99.

Newman, John. 2008. Aiming low in linguistics: Low-level generalizations in corpusbased research. Proceedings of the 11th International Symposium on Chinese Languages and Linguistics, National Chiao Tung University, Hsinchu, Taiwan. May 24 2008. http://www.ualberta.ca/ johnnewm/Aiming\%20Low.pdf.

Newman, John and Sally Rice. 2006. Transitivity schemas of English EAT and DRINK in the BNC. In and Anatol Stefanowitsch (eds.), Corpora in Cognitive Linguistics: Corpus-Based Approaches to Syntax and Lexis, 225-260. Berlin: Mouton de Gruyter.

Nuyts, Jan. 2001. Epistemic modality, language, and conceptualization: A cognitivepragmatic perspective. Amsterdam: John Benjamins. 
Nuyts, Jan. 2007. Cognitive linguistics and functional linguistics. In D.Geeraerts, H. Cuyckens (eds.), Handbook of cognitive linguistics, 543-565. Oxford: Oxford University Press.

Ožegov, S. I. and N. Ju. Švedova. 2001. Slovar' russkogo jazyka. Moscow: Russkij jazyk.

Padučeva, Elena V. 1996. Sematičeskie issledovanija. Semantika vremeni i vida v russkom jazyke. Semantika narrativa. Moscow: Jazyki russkoj kul’tury.

Pul'kina, Il'za M. and Ekaterina B. Zaxava-Nekrasova. 1977. Učebnik russkogo jazyka. Moscow: Russkij jazyk.

Rice, Sally and John Newman. 2005. Inflectional islands. Presentation at the $9^{\text {th }}$ International Cognitive Linguistics Conference, Yonsei University, Seoul, Korea. Available at http://www.ualbera.ca/ johnnewm.

Šatunovskij, Il'ja B. 2002. Nesoveršennyj vs. soveršennyj vid v imperative. In: Nina Arutjunova, V. Apresjan and Anatolij Baranov (eds.), Logičeskij analiz jazyka: Semantika načala i konca, 267-309. Moscow: Indrik.

Šatunovskij, Il’ja B. 2009. Problemy russkogo vida. Moscow: Jazyki slavjanskix kul'tur.

Šaxmatov, A. A. 1941. Sintaksis russkogo jayzka (Russian syntax). Leningrad. Učpedgiz.

Schooneveld, Cornelius H. van. The so-called 'préverbe vides' and neutralization. In Dutch contributions to the Fourth International Congress of Slavistics, 159-161. The Hague: Mouton, 1958.

Šmelev, Alexej and Anna Zaliznjak. 2006. Aspect, modality, and closely-related categories in Russian. Paper presented at the Slavic Linguistics Society Conference in at Indiana University.

Stefanowitsch, Anatol and Stefan Th. Gries. 2003. Collostructions: Investigating the interaction of words and constructions. International Journal of Corpus Linguistics 8, 209-243.

Šteinfeldt, E. 1970. Russian Word Count. Moscow: Progress.

Stubbs, Michael. 2001. Words and Phrases: Corpus Studies of Lexical Semantics. Oxford: Blackwell.

Švedova, N. Ju. et al. 1980. Russkaja grammatika, tom I. Moscow: Nauka.

Tabachnik, Barbara G. and Linda S. Fidell. 2007. Using Multivariate Statistics. Boston: Pearson. 
Timberlake, Alan. 2004. A Reference Grammar of Russian. Cambridge: Cambridge University Press.

Vey, M. “Les préverbes 'vides' en tchéque moderne.” Revue des études slaves 29 (1952): 82-107.

Vinogradov, V. V. 1938. Sovremennyj russkij jazyk. Grammatičeskoe učenie o slove. Moscow: Učpedgiz.

Wade, Terence. 1992. A Comprehensive Russian Grammar. Oxford: Blackwell.

Zaliznjak, Andrej. 1980. Grammatičeskij slovar' russkogo jazyka. Moscow: Russkij jazyk.

Zaliznjak, A. A. and A. D. Šmelev. 2000. Vvedenie v russkuju aspektologiju.

Moscow: Jazyki russkoj kul'tury.

\section{Appendix A: Imperfective imperative}

\begin{tabular}{|c|c|c|c|c|c|}
\hline bljusti & bljudi(te) & $\begin{array}{l}\text { 'observe (the laws); take care (of } \\
\text { yourself)' }\end{array}$ & 21 & $10 \%$ & 0.71 \\
\hline bojat'sja & boj(te)s' & 'be afraid' & 1690 & $8 \%$ & 0.69 \\
\hline brosat' & $\operatorname{brosaj}(t e)$ & 'throw; stop doing that' & 361 & $9 \%$ & 0.6 \\
\hline vnimat' & vnimaj(te) & 'pay attention' & 36 & $9 \%$ & $0.6^{\circ}$ \\
\hline volnovat'sja & ne volnujsja(tes') & 'don't be nervous' & 1039 & $28 \%$ & 0.5 \\
\hline vstavat' & vstavaj(te) & 'stand up' & 702 & $14 \%$ & 0.8 \\
\hline vstrevat' & ne vstrevaj(te) & 'don't butt in' & 19 & $16 \%$ & 0.8 \\
\hline vybirat' & vybiraj(te) & 'choose' & 473 & $9 \%$ & 0.5 \\
\hline vydumyvat' & ne vydumyvaj(te) & 'don't invent excuses' & 70 & $12 \%$ & 0.7 \\
\hline vyzdoravlivat' & vyzdoravlivaj(te) & 'get well' & 62 & $27 \%$ & 0.5 \\
\hline vykladyvat' & vykladyvaj(te) & 'tell' & 140 & $23 \%$ & 0.7 \\
\hline vyključat' & vyključaj(te) & 'turn off' & 33 & $9 \%$ & 0.5 \\
\hline vykručivat'sja & vykručivajsja(tes') & 'slip out' & 14 & $8 \%$ & 0.57 \\
\hline vyručat' & $\begin{array}{l}\text { vyručaj(te) } \\
\text { ne }\end{array}$ & $\begin{array}{l}\text { 'help; try to help me' } \\
\text { 'don't make yourself out to be better than }\end{array}$ & 80 & $14 \%$ & 0.7 \\
\hline vysovyvat'sja & vysovyvajsja(tes') & you are' & 51 & $11 \%$ & 0.78 \\
\hline vysylat' & vysylaj(te) & 'send' & 32 & $10 \%$ & 0.2 \\
\hline gljadet' & gljadi(te) & 'look' & 1260 & $16 \%$ & 0.83 \\
\hline gresti & grebi(te) & 'row; get out of here' & 57 & $11 \%$ & 0.8 \\
\hline gruzit'sja & gruzis'(tes') & ‘embark; worry’ & 17 & $11 \%$ & 0.82 \\
\hline davat' & davaj(te) & 'give; 'let's do smth.' & 4964 & $15 \%$ & 0.73 \\
\hline dogovarivat' & dogovarivaj(te) & 'finish; speak' & 32 & $24 \%$ & 0.53 \\
\hline doedat' & doedaj(te) & 'finish eating' & 18 & $13 \%$ & 0.72 \\
\hline$\check{z} a t^{\prime}$ & žmi(te) & 'squeeze; hurry up' & 125 & $12 \%$ & \\
\hline zabirat' & zabiraj(te) & 'take' & 259 & $15 \%$ & \\
\hline zabyvat' & ne zabyvaj(te) & 'don't forget' & 690 & $14 \%$ & 0.43 \\
\hline zaezžat' & zaezžaj(te) & 'call in on the way' & 42 & $11 \%$ & 0.48 \\
\hline zakurivat' & zakurivaj(te) & 'smoke' & 26 & $9 \%$ & 0.6 \\
\hline
\end{tabular}




\begin{tabular}{|c|c|c|c|c|c|}
\hline zakusyvat' & zakusyvaj(te) & 'eat chasers' & 55 & $11 \%$ & 0.76 \\
\hline zalezat' & zalezaj(te) & 'get into (the car)' & 56 & $14 \%$ & 0.66 \\
\hline zapasat'sja & zapasajsja(tes') & 'take' & 11 & $11 \%$ & 0.09 \\
\hline zapevat' & zapevaj(te) & 'start singing' & 16 & $12 \%$ & 0.75 \\
\hline zapisyvat' & zapisyvaj(te) & 'write down' & 173 & $8 \%$ & 0.42 \\
\hline zapominat' & zapominaj(te) & 'remember' & 93 & $13 \%$ & 0.69 \\
\hline zaprjagat' & zaprjagaj(te) & 'harness; let's get started' & 18 & $13 \%$ & 0.78 \\
\hline zvonit' & zvoni(te) & 'ring' & 794 & $9 \%$ & 0.43 \\
\hline$i d t i$ & idi(te) & 'go; come' & 6507 & $8 \%$ & 0.69 \\
\hline izvinjat' & izvinjaj(te) & 'excuse’ & 62 & $48 \%$ & 0.18 \\
\hline končat' & končaj(te) & 'stop' & 362 & $25 \%$ & 0.82 \\
\hline lenit'sja & ne lenis'(tes') & 'don't be lazy' & 32 & $15 \%$ & 0.75 \\
\hline ložit'sja & ložis'(tes') & 'lie down' & 544 & $18 \%$ & 0.77 \\
\hline lopat' & lopaj(te) & 'eat up’ & 14 & $11 \%$ & 0.79 \\
\hline nagovarivat' & ne nagovarivaj(te) & 'don't slander' & 9 & $8 \%$ & 0.67 \\
\hline nakručivat' & ne nakručivaj(te) & 'don't exaggerate' & 18 & $11 \%$ & 0.44 \\
\hline nalivat' & nalivaj(te) & 'fill (with wine)' & 163 & $17 \%$ & 0.74 \\
\hline naslaždat'sja & naslaždajsja(tes') & ‘enjoy’ & 99 & $9 \%$ & 0.39 \\
\hline obižat' & ne obižaj(te) & 'don’t offend' & 104 & $9 \%$ & 0.55 \\
\hline obižat'sja & ne obižajsja(tes') & 'don't be offended' & 460 & $25 \%$ & 0.58 \\
\hline obogaščat'sja & obogaščajsja(tes') & 'be prosperous' & 24 & $17 \%$ & 0.04 \\
\hline obraščat' & obraščaj(te) & 'mind' & 375 & $9 \%$ & 0.45 \\
\hline ogorčat'sja & ne ogorčajsja(tes') & 'don't get upset' & 123 & $29 \%$ & 0.41 \\
\hline odevat'sja & odevajsja(tes') & 'get dressed' & 176 & $11 \%$ & 0.67 \\
\hline otvalivat' & otvalivaj(te) & 'get out of here' & 22 & $19 \%$ & 0.95 \\
\hline otvlekat'sja & ne otvlekajsja(tes') & 'don't distract' & 66 & $12 \%$ & 0.61 \\
\hline otvorjat' & otvorjaj(te) & 'open (the gate)' & 18 & $18 \%$ & 0.89 \\
\hline otpravljat'sja & otpravljajsja(tes') & 'go' & 169 & $8 \%$ & 0.45 \\
\hline otčaivat’sja & ne otčaivajsja(tes') & 'don’t despair' & 81 & $37 \%$ & 0.41 \\
\hline perebivat' & ne perebivaj(te) & 'don't interrupt' & 139 & $18 \%$ & 0.65 \\
\hline peredergivat' & ne peredergivaj(te) & 'don't distort the facts' & 18 & $15 \%$ & 0.89 \\
\hline podavat' & podavaj(te) & 'bring' & 295 & $9 \%$ & 0.78 \\
\hline podključat’ & podključaj(te) & ‘link up’ & 14 & $8 \%$ & 0.43 \\
\hline podsaživat'sja & podsaživajsja(tes') & 'take a seat (near us)' & 16 & $12 \%$ & 0.31 \\
\hline podyxat’ & $\operatorname{podyxaj}(t e)$ & 'kick the bucket' & 18 & $13 \%$ & 0.72 \\
\hline pozorit' & ne pozor'(te) & $\begin{array}{l}\text { 'don't dishonor (self or parents)' } \\
\text { 'mention; bear no ill will; vanish into thin }\end{array}$ & 26 & $13 \%$ & 0.73 \\
\hline pominat' & pominaj(te) & air' & 117 & $21 \%$ & 0.79 \\
\hline popravljat'sja & popravljajsja(tes') & 'get well' & 69 & $28 \%$ & 0.59 \\
\hline prenebregat' & ne prenebregaj(te) & 'neglect' & 32 & $8 \%$ & 0.13 \\
\hline pridirat'sja & ne pridirajsja(tes') & 'don’t nag; don't pick on' & 23 & $9 \%$ & 0.57 \\
\hline priezžat' & $\begin{array}{l}\text { priezžaj(te) } \\
\text { ne }\end{array}$ & 'come' & 899 & $13 \%$ & 0.53 \\
\hline prikidyvat'sja & prikidyvajsja(tes') & 'don't pretend to be smth. you aren't' & 39 & $13 \%$ & 0.87 \\
\hline prisoedinjat'sja & prisoedinjajsja(tes') & 'come join us at the table' & 90 & $14 \%$ & 0.42 \\
\hline pristupat' & pristupaj(te) & 'get busy' & 94 & $12 \%$ & 0.37 \\
\hline prisylat’ & prisylaj(te) & 'send' & 119 & $14 \%$ & 0.19 \\
\hline
\end{tabular}




\begin{tabular}{|c|c|c|c|c|c|}
\hline pritvorjat'sja & $\begin{array}{l}\text { ne } \\
\text { pritvorjajsja(tes') }\end{array}$ & 'don't pretend' & 58 & $8 \%$ & 0.72 \\
\hline provalivat' & provalivaj(te) & 'get out of here' & 80 & $64 \%$ & 0.79 \\
\hline proščat' & proščaj(te) & ‘adieu’' & 1324 & $55 \%$ & 0.68 \\
\hline razdevat'sja & razdevajsja(tes') & 'take off one's coat' & 169 & $25 \%$ & 0.53 \\
\hline razevat' & $\begin{array}{l}\text { razevaj(te) } \\
\text { ne }\end{array}$ & 'don't open your mouth' & 14 & $11 \%$ & 1.00 \\
\hline rasstraivat'sja & rasstraivajsja(tes') & 'don't get upset' & 225 & $38 \%$ & 0.51 \\
\hline robet' & ne robej(te) & 'don’t be shy' & 52 & $19 \%$ & 0.81 \\
\hline sadit'sja & sadis'(tes') & 'sit down' & 1854 & $31 \%$ & 0.58 \\
\hline svalivat' & svalivaj(te) & 'get out of here' & 24 & $8 \%$ & 0.75 \\
\hline serdit'sja & ne serdis'(tes') & 'don't get annoyed' & 351 & $21 \%$ & 0.65 \\
\hline skidyvat' & skidyvaj(te) & 'take off (shoes)' & 10 & $8 \%$ & 0.90 \\
\hline slezat' & slezaj(te) & 'get out (of the car)' & 86 & $32 \%$ & 0.84 \\
\hline smet' & ne smej(te) & 'don't do it' & 476 & $21 \%$ & 0.80 \\
\hline smotret' & smotri(te) & 'look' & 5881 & $13 \%$ & 0.64 \\
\hline smuščat'sja & ne smuščajsja(tes') & 'don't be shy' & 37 & $11 \%$ & 0.46 \\
\hline soedinjat'sja & soedinjajsja(tes') & 'unite' & 58 & $8 \%$ & 0.00 \\
\hline soznavat'sja & soznavajsja(tes') & 'tell the truth' & 21 & $8 \%$ & 0.71 \\
\hline spasat'sja & spasajsja(tes') & 'save yourself' & 80 & $14 \%$ & 0.68 \\
\hline stesnjat'sja & ne stesnjajsja(tes') & 'don't hesitate' & 299 & $15 \%$ & 0.42 \\
\hline stupat' & stupaj(te) & 'get going' & 663 & $57 \%$ & 0.67 \\
\hline toropit'sja & toropis'(tes') & 'be quick' & 385 & $12 \%$ & 0.53 \\
\hline ubirat'sja & ubirajsja(tes') & 'get out of here' & 206 & $36 \%$ & 0.55 \\
\hline uvol'njat'sja & uvol'njajsja(tes') & 'quit' & 15 & $10 \%$ & 0.87 \\
\hline utešat'sja & utešajsja(tes') & 'be comforted' & 14 & $10 \%$ & 0.43 \\
\hline xvalit'sja & ne xvalis'(tes') & 'don’t brag' & 16 & $8 \%$ & 0.88 \\
\hline xvastat' & ne xvastaj(te) & 'don’t brag' & 18 & $9 \%$ & 0.39 \\
\hline jazvit' & ne jazvi(te) & 'don't be sarcastic' & 33 & $26 \%$ & 1.00 \\
\hline
\end{tabular}

\section{Appendix B: Perfective imperative}

$\begin{array}{ll}\text { blagoslovit' } & \text { blagoslovi(te) } \\ \text { brosit' } & \text { bros'(te) } \\ \text { vgljadet'sja } & \text { vgljadis'(tes') } \\ \text { vzvesit' } & \text { vzves'(te) } \\ \text { vzgljanut' } & \text { vzgljani(te) } \\ \text { vlit' } & \text { vlej(te) } \\ \text { voobrazit' } & \text { voobrazi(te) } \\ \text { vskipjatit' } & \text { vskipjati(te) } \\ \text { vslušat'sja } & \text { vslušajsja(tes') } \\ \text { vsmotret'sja } & \text { vsmotris'(tes') } \\ \text { vyključit' } & \text { vyključi(te) } \\ \text { vysušit' } & \text { vysuši(te) } \\ \text { dat' } & \text { daj(te) } \\ \text { dopustit' } & \text { dopusti(te) }\end{array}$

'(God) bless you'

'stop; leave, enough about it'

'look closely'

'weigh; consider'

'look'

'pour in'

'imagine'

'boil'

'listen'

'look closely'

'turn off'

'dry up'

'let'

'suppose' $\begin{array}{lll}124 & 20 \% & 0.81\end{array}$

$1289 \quad 12 \% \quad 0.72$

$\begin{array}{lll}40 & 10 \% & 0.43\end{array}$

$\begin{array}{lll}36 & 10 \% & 0.19\end{array}$

$\begin{array}{lll}428 & 9 \% & 0.39\end{array}$

$\begin{array}{lll}23 & 8 \% & 0.43\end{array}$

$\begin{array}{lll}183 & 18 \% & 0.35\end{array}$

$\begin{array}{lll}15 & 12 \% & 0.40\end{array}$

$39 \quad 25 \% \quad 0.33$

$\begin{array}{lll}22 & 8 \% & 0.09\end{array}$

$\begin{array}{lll}112 \quad 10 \% & 0.64\end{array}$

$\begin{array}{lll}17 & 9 \% & 0.65\end{array}$

$\begin{array}{lll}7747 & 15 \% & 0.68\end{array}$

$3006 \quad 50 \% \quad 0.01$ 


\begin{tabular}{|c|c|c|c|c|c|}
\hline$z a b y t^{\prime}$ & (ne) zabud'(te) & 'don't forget' & 1413 & $9 \%$ & 0.47 \\
\hline zavalit'sja & zavalis'(tes') & 'be toppled' & 40 & $9 \%$ & 0.98 \\
\hline zavarit' & zavari(te) & 'brew' & 35 & $11 \%$ & 0.40 \\
\hline zakryt' & zakroj(te) & 'close’ & 438 & $8 \%$ & 0.53 \\
\hline zalit' & zalej(te) & ‘fill up’ & 130 & $12 \%$ & 0.12 \\
\hline zalit'sja & zalejsja(tes') & $\begin{array}{l}\text { 'be poured' } \\
\text { 'don't forget to take smth. with }\end{array}$ & 28 & $11 \%$ & 1.00 \\
\hline zapastis' & zapasis'(tes') & you' & 21 & $8 \%$ & 0.14 \\
\hline zapisat' & zapishi(te) & 'write down' & 285 & $9 \%$ & 0.39 \\
\hline zapomnit' & zapomni(te) & 'you must remember' & 804 & $20 \%$ & 0.60 \\
\hline izbavit' & izbav'(te), izbavi & '(God) forfend' & 156 & $19 \%$ & 0.86 \\
\hline izvinit' & $i z \operatorname{vini}(t e)$ & 'forgive' & 5367 & $97 \%$ & 0.30 \\
\hline nalit' & nalej(te) & 'pour' & 313 & $14 \%$ & 0.67 \\
\hline napomnit' & napomni(te) & 'remind' & 965 & $18 \%$ & 0.03 \\
\hline naprjač’ & naprjagi(te) & 'tense; use your brain' & 39 & $16 \%$ & 0.54 \\
\hline nateret' & natri(te) & 'rub' & 20 & $12 \%$ & 0.55 \\
\hline načertit' & nacherti(te) & 'draw' & 14 & $11 \%$ & 0.36 \\
\hline obratit' & obrati(te) (vnimanie) & 'notice' & 900 & $16 \%$ & 0.13 \\
\hline obyskat' & obyščilte) & 'search smb.' & 22 & $8 \%$ & 0.41 \\
\hline ostavit' & ostav'(te) & 'stop; leave smb. alone' & 1758 & $13 \%$ & 0.39 \\
\hline otvalit' & otvali(te) & 'push off; get out of here' & 79 & $22 \%$ & 0.87 \\
\hline otvorit' & otvori(te) & 'open (the gate)' & 36 & $10 \%$ & 0.50 \\
\hline otdoxnut' & otdoxni(te) & 'take a rest' & 222 & $9 \%$ & 0.66 \\
\hline otmetit' & otmet'$^{\prime}($ te $)$ & 'note' & 884 & $9 \%$ & 0.01 \\
\hline otpustit’ & otpusti(te) & 'let smb. go; forgive' & 544 & $14 \%$ & 0.57 \\
\hline otstat' & otstan'(te) & 'get out of here' & 325 & $23 \%$ & 0.75 \\
\hline oxladit' & oxladi(te) & 'chill' & 25 & $9 \%$ & 0.16 \\
\hline očistit' & očist'(ite) & 'clean' & 77 & $9 \%$ & 0.35 \\
\hline perestat' & perestan'(te) & ‘stop’ & 891 & $10 \%$ & 0.68 \\
\hline perečislit’ & perečisli(te) & 'enumerate' & 100 & $9 \%$ & 0.06 \\
\hline pobojat'sja & pobojsja(tes') & 'do you not fear God' & 54 & $8 \%$ & 0.35 \\
\hline poverit' & pover'(te) & 'believe' & 1475 & $18 \%$ & 0.29 \\
\hline pogljadet' & pogljadi(te) & 'look’' & 406 & $15 \%$ & 0.61 \\
\hline poguljat' & poguljaj(te) & 'take a walk' & 109 & $10 \%$ & 0.40 \\
\hline podogret' & podogrej(te) & ‘warm up' & 10 & $8 \%$ & 0.20 \\
\hline podskazat' & podskazhi(te) & 'tell' & 324 & $16 \%$ & 0.10 \\
\hline podumat' & podumaj(te) & 'think of' & 1898 & $8 \%$ & 0.43 \\
\hline požalovat' & požaluj(te) & 'come; perhaps' & 170 & $21 \%$ & 0.21 \\
\hline pozvat' & pozovi(te) & 'call' & 320 & $8 \%$ & 0.54 \\
\hline pozvolit' & pozvol'(te) & 'let' & 1503 & $11 \%$ & 0.11 \\
\hline pokljast'sja & pokljanis'(tes') & 'take an oath; swear' & 64 & $10 \%$ & 0.63 \\
\hline pokurit' & pokuri(te) & ‘smoke’ & 104 & $14 \%$ & 0.28 \\
\hline polenit'sja & ne polenis'(tes') & 'don't be lazy' & 46 & $15 \%$ & 0.22 \\
\hline polit' & $\operatorname{polej}(t e)$ & 'pour (upon)' & 23 & $8 \%$ & 0.22 \\
\hline
\end{tabular}




\begin{tabular}{|c|c|c|c|c|c|}
\hline poljubovat'sja & poljubujsja(tes') & 'look at smth.' & 140 & $24 \%$ & 0.46 \\
\hline pomilovat' & pomiluj(te) & 'for goodness' sake' & 441 & $76 \%$ & 0.55 \\
\hline pomolit'sja & pomolis'(tes') & 'pray’' & 59 & $16 \%$ & 0.71 \\
\hline pomoč’ & pomogi(te) & 'help' & 1600 & $8 \%$ & 0.45 \\
\hline pomjanut' & pomjani(te) & 'mention; mark my words' & 123 & $23 \%$ & 0.50 \\
\hline ponjuxat' & ponjuxaj(te) & 'sniff' & 47 & $10 \%$ & 0.57 \\
\hline posvetit' & posveti(te) & 'hold a light' & 22 & $20 \%$ & 0.73 \\
\hline posmotret' & posmotri(te) & 'look' & 4251 & $16 \%$ & 0.42 \\
\hline postarat'sja & postarajsja(tes') & 'try' & 899 & $23 \%$ & 0.32 \\
\hline postoronit'sja & postoronis'(tes') & 'step aside' & 35 & $18 \%$ & 0.89 \\
\hline postojat' & postoj(te) & 'wait' & 858 & $33 \%$ & 0.66 \\
\hline poterpet' & poterpi(te) & 'be patient' & 351 & $24 \%$ & 0.68 \\
\hline potoropit'sja & potoropis'(tes') & 'hurry up' & 55 & $13 \%$ & 0.49 \\
\hline poščadit' & poščadi(te) & 'spare one's life' & 66 & $22 \%$ & 0.52 \\
\hline poščupat' & poščupaj(te) & 'touch' & 28 & $8 \%$ & 0.75 \\
\hline predstavit' & predstav'(te) & 'imagine' & 2852 & $21 \%$ & 0.24 \\
\hline prekratit' & prekrati(te) & 'stop it' & 518 & $16 \%$ & 0.50 \\
\hline prigljadet'sja & prigljadis'(tes') & 'look closely' & 59 & $15 \%$ & 0.47 \\
\hline prideržat' & priderži (te) & 'restrain; curb (your dog)' & 34 & $11 \%$ & 0.79 \\
\hline prikinut' & prikin'(te) & 'go figure' & 240 & $31 \%$ & 0.77 \\
\hline prilaskat' & prilaskaj(te) & 'caress' & 13 & $8 \%$ & 0.62 \\
\hline prislušat'sja & prislušajsja(tes') & 'listen’ & 96 & $8 \%$ & 0.25 \\
\hline prismotret' & prismotris'(tes') & 'take care of smb.' & 27 & $19 \%$ & 0.63 \\
\hline prismotret'sja & prismotris'(tes') & 'regard smb. closely' & 107 & $19 \%$ & 0.28 \\
\hline prišit' & prišej(te) & 'sew (to)' & 43 & $12 \%$ & 0.72 \\
\hline proverit' & prover'(te) & 'check' & 444 & $9 \%$ & 0.36 \\
\hline prokonsul'tirovat'sja & prokonsul'tirujsja(tes') & 'consult' & 29 & $15 \%$ & 0.14 \\
\hline promyt' & $\operatorname{promoj}(t e)$ & 'wash out' & 44 & $12 \%$ & 0.07 \\
\hline prostit' & prosti(te) & 'excuse’ & 5474 & $65 \%$ & 0.40 \\
\hline proteret' & protri(te) & 'wipe; take a better look' & 52 & $11 \%$ & 0.52 \\
\hline pustit' & pusti(te) & 'let smb. go' & 475 & $12 \%$ & 0.64 \\
\hline razbavit' & razbav'(te) & 'dilute’ & 10 & $10 \%$ & 0.30 \\
\hline razvjazat' & razvjaži(te) & 'untie' & 56 & $9 \%$ & 0.57 \\
\hline razlit' & razlej(te) & 'pour out' & 35 & $8 \%$ & 0.74 \\
\hline razogret' & razogrej(te) & ‘warm up’ & 14 & $9 \%$ & 0.57 \\
\hline razodrat' & razderi(te) & 'tear; damn' & 10 & $9 \%$ & 1.00 \\
\hline razrešit' & razreši(te) & ‘allow' & 797 & $18 \%$ & 0.09 \\
\hline raspisat'sja & raspišis'(tes') & ‘sign’ & 109 & $16 \%$ & 0.23 \\
\hline rasskazat' & rasskaži(te) & 'tell' & 1915 & $10 \%$ & 0.45 \\
\hline rasslabit' & rasslab'(te) & 'relax (tight muscles)' & 43 & $31 \%$ & 0.21 \\
\hline rasslabit'sja & rasslab'sja(tes') & 'relax' & 168 & $15 \%$ & 0.52 \\
\hline rassmotret' & rassmotri(te) & 'see (figure x)' & 849 & $24 \%$ & 0.01 \\
\hline rastvorit' & rastvori(te) & 'dissolve' & 18 & $10 \%$ & 0.33 \\
\hline rasteret' & razotri(te) & 'rub’ & 29 & $12 \%$ & 0.38 \\
\hline
\end{tabular}




$\begin{array}{ll}\text { slit' } & \text { slej(te) } \\ \text { smazat' } & \text { smaž'(te) } \\ \text { soglasit'sja } & \text { soglasis'(tes') } \\ \text { sognut' } & \text { sogni(te) } \\ \text { sogret' } & \text { sogrej(te) } \\ \text { spasti } & \text { spasi(te) } \\ \text { stancevat' } & \text { stancuj(te) } \\ \text { ubrat' } & \text { uberi(te) } \\ \text { uvolit' } & \text { uvol'(te) } \\ \text { ugadat' } & \text { ugadaj(te) } \\ \text { umnožit' } & \text { umnož'(te) } \\ \text { umyt'sja } & \text { umojsja(tes') } \\ \text { unjat'sja } & \text { ujmis'(tes') } \\ \text { uspokoit'sja } & \text { uspokojsja(tes') } \\ \text { utešit'sja } & \text { utešs'sja(tes') } \\ \text { učest' } & \text { učti(te) }\end{array}$

'pour off'
'smear (the door)'
'you must admit'
'bend'
'warm'
'save'
'dance'
'hands off; get this out of here'
'stop, I don't want to speak about
it'
'guess'
'multiply'
'wash up'
'keep still'
'calm down'
'be comforted'
'keep in mind'

$\begin{array}{rrr}26 & 9 \% & 0.15 \\ 29 & 9 \% & 0.24 \\ 1004 & 8 \% & 0.16 \\ 33 & 13 \% & 0.27 \\ 22 & 8 \% & 0.77 \\ 504 & 8 \% & 0.63 \\ 17 & 11 \% & 0.71 \\ 508 & 14 \% & 0.50 \\ & & \\ 136 & 12 \% & 0.12 \\ 167 & 10 \% & 0.67 \\ 20 & 11 \% & 0.40 \\ 48 & 10 \% & 0.81 \\ 59 & 35 \% & 0.76 \\ 848 & 24 \% & 0.68 \\ 11 & 8 \% & 0.82 \\ 735 & 24 \% & 0.51\end{array}$

\section{Appendix C: Perfective non-past}

$\begin{array}{lllrl}\text { vleč' } & \text { vlečet } & \text { 'entail' } & 1555 & 85 \% \\ \text { vozrasti } & \text { vozrastet } & \text { 'grow' } & 490 & 24 \% \\ \text { vozrodit'sja } & \text { vozroditsja } & \text { 'revive' } & 75 & 27 \% \\ \text { vosstanovit'sja } & \text { vosstanovitsja } & \text { 'be restored' } & 81 & 25 \% \\ \text { vygnat' } & \text { vygonit } & \text { 'drive out, expel' } & 428 & 24 \% \\ \text { vyzdorovet' } & \text { vyzdoroveet } & \text { 'get well' } & 110 & 28 \% \\ \text { vykrutit'sja } & \text { vykrutitsja } & \text { 'get oneself out of trouble' } & 66 & 29 \% \\ \text { vylit'sja } & \text { vyl'etsja } & \text { 'flow out' } & 132 & 27 \% \\ \text { vymeret' } & \text { vymret } & \text { 'die out' } & 96 & 27 \% \\ \text { vysoxnut' } & \text { vysoxnet } & \text { 'dry up' } & 132 & 29 \% \\ \text { vyjasnjat'sja } & \text { vyjasnjaetsja } & \text { 'be explained' } & 805 & 89 \% \\ \text { dožit' } & \text { doživet } & \text { 'live until, come to' } & 369 & 26 \% \\ \text { dotjanut' } & \text { dotjanet } & \text { 'hold out until' } & 103 & 25 \% \\ \text { zagnut'sja } & \text { zagnetsja } & \text { 'die' } & 59 & 49 \% \\ \text { zamerznut' } & \text { zamerznet } & \text { 'freeze to death' } & 232 & 25 \% \\ \text { zapolnit'sja } & \text { zapolnitsja } & \text { 'fill up' } & 35 & 29 \% \\ \text { zatrudnit' } & \text { zatrudnit } & \text { 'make things difficult' } & 83 & 50 \% \\ \text { zatrudnjat'sja } & \text { zatrudnjaetsja } & \text { 'be made difficult' } & 275 & 86 \% \\ \text { isčerpyvat' } & \text { isčerpyvaet } & \text { 'exhaust' } & 100 & 89 \% \\ \text { kasat'sja } & \text { kasaetsja } & \text { 'concern' } & 9719 & 87 \% \\ \text { naladit'sja } & \text { naladitsja } & \text { 'work out well' } & 193 & 40 \% \\ \text { obojtis' } & \text { obojdetsja } & \text { 'I'll manage without' } & 1642 & 32 \% \\ \text { obslužit' } & \text { obslužit } & \text { 'serve' } & 40 & 26 \% \\ \text { objazyvat'sja } & \text { objazyvaetsja } & \text { 'be obliged to' } & 480 & 92 \% \\ \text { ogovorit'sja } & \text { ogovorjus': ... } & \text { 'make a reservation' } & 112 & 33 \% \\ \text { ograničit'sja } & \text { ograničus' liš' tem } \ldots \text {... } & \text { 'not go beyond' } & 305 & 25 \%\end{array}$




\begin{tabular}{|c|c|c|c|c|}
\hline okazyvat'sja & okazyvaetsja & 'turn out to be' & 10869 & $85 \%$ \\
\hline okupit'sja & okupitsja & 'will be rewarded, will pay off' & 130 & $73 \%$ \\
\hline osmelit'sja & osmeljus' zametit'... & 'dare, take the liberty of' & 239 & $35 \%$ \\
\hline otvalit'sja & otvalitsja & 'fall off' & 86 & $26 \%$ \\
\hline otpugnut' & otpugnet & 'frighten off' & 34 & $27 \%$ \\
\hline otrazit'sja & otrazitsja & 'be reflected' & 372 & $27 \%$ \\
\hline oštrafovat' & oštrafuet & 'fine' & 41 & $25 \%$ \\
\hline peresečsja & peresečetsja & 'intersect' & 54 & $27 \%$ \\
\hline pobojat'sja & ne pobojus' skazat' ... & 'don't fear' & 168 & $24 \%$ \\
\hline povleč & povlečet & 'entail' & 181 & $25 \%$ \\
\hline povtorit'sja & povtorjus', chto ... & 'repeat' & 569 & $46 \%$ \\
\hline povysit'sja & povysitsja & 'rise' & 165 & $27 \%$ \\
\hline podoxnut' & podoxnet & 'die' & 106 & $45 \%$ \\
\hline podpustit' & podpustit & 'allow to approach' & 77 & $33 \%$ \\
\hline podrasti & podrastet & 'grow a little' & 182 & $32 \%$ \\
\hline podskazat' & podskažet & 'tell' & 549 & $27 \%$ \\
\hline podtverždat'sja & podtverždaetsja & 'be confirmed' & 677 & $83 \%$ \\
\hline poželat’' & vragu ne poželaeš’ & $\begin{array}{l}\text { 'I wouldn't wish it on my worst } \\
\text { enemy' }\end{array}$ & 498 & $24 \%$ \\
\hline pozvolit' & pozvolju zametit'... & 'let oneself' & 4491 & $34 \%$ \\
\hline pojti & tak ne pojdet & 'that won't work' & 12107 & $24 \%$ \\
\hline poletet' & poletit & 'fly' & 623 & $25 \%$ \\
\hline polučit'sja & polučitsja & 'turn out' & 3539 & $28 \%$ \\
\hline pomeret' & pomret & 'die' & 479 & $35 \%$ \\
\hline pomestit'sja & pomestitsja & 'fit in, find a place' & 122 & $33 \%$ \\
\hline pomoč & pomožet & 'help' & 4964 & $26 \%$ \\
\hline popravit'sja & popravitsja & 'get better, put on weight' & 183 & $26 \%$ \\
\hline posmet' & posmeju zametit' & 'dare' & 284 & $34 \%$ \\
\hline posposobstvovat' & posposobstvuet & 'assist' & 29 & $24 \%$ \\
\hline postarat'sja & postaraetsja & 'try' & 1372 & $35 \%$ \\
\hline potrebovat'sja & potrebuetsja & 'be necessary' & 1385 & $57 \%$ \\
\hline prevysit' & prevysit & 'exceed' & 256 & $24 \%$ \\
\hline predopredeljat'sja & predopredeljaetsja & 'be predetermined' & 34 & $85 \%$ \\
\hline predstavit'sja & predstavitsja & 'arise' & 993 & $37 \%$ \\
\hline pridrat'sja & ne prideresh'sja & 'won't find fault with' & 69 & $28 \%$ \\
\hline prijtis' & pridetsja & 'have to' & 10292 & $42 \%$ \\
\hline priložit'sja & priložitsja & 'put near' & 78 & $27 \%$ \\
\hline pripomnit' & pripomnit & 'remind' & 351 & $29 \%$ \\
\hline prišit' & priš'et & 'kill, judge unjustly' & 90 & $26 \%$ \\
\hline prodlit'sja & prodlitsja & 'last' & 318 & $67 \%$ \\
\hline prodolžit'sja & prodolžitsja & 'continue' & 229 & $49 \%$ \\
\hline prokljast' & prokljanet & 'curse' & 58 & $28 \%$ \\
\hline prorasti & prorastet & 'sprout' & 50 & $25 \%$ \\
\hline procitirovat' & procitiruju ... & 'quote' & 114 & $25 \%$ \\
\hline razmazat' & razmažet & 'spread' & 31 & $26 \%$ \\
\hline razobrat'sja & razberetsja & 'make sense of' & 1393 & $27 \%$ \\
\hline
\end{tabular}




$\begin{array}{lllrl}\text { razorit'sja } & \text { razoritsja } & \text { 'go broke' } & 74 & 29 \% \\ \text { razrešit'sja } & \text { razrešitsja } & \text { 'be solved' } & 82 & 26 \% \\ \text { razrušit'sja } & \text { razrušitsja } & \text { 'collapse' } & 45 & 24 \% \\ \text { rasterzat' } & \text { rasterzaet } & \text { 'tear to pieces' } & 37 & 27 \% \\ \text { svestis' } & \text { svedetsja } & \text { 'come to something' } & 54 & 24 \% \\ \text { sgnit' } & \text { sgniet } & \text { 'rot; die' } & 75 & 33 \% \\ \text { skazat'sja } & \text { skažetsja } & \text { 'will have an effect' } & 399 & 25 \% \\ \text { slopat' } & \text { slopaet } & \text { 'devour' } & 41 & 25 \% \\ \text { sogret' } & \text { sogreet } & \text { 'warm up' } & 78 & 27 \% \\ \text { sožrat' } & \text { sožret } & \text { 'devour' } & 161 & 36 \% \\ \text { spast' } & \text { spaset } & \text { 'save' } & 89 & 51 \% \\ \text { spravit'sja } & \text { spravitsja } & \text { 'cope' } & 991 & 27 \% \\ \text { stancevat' } & \text { stancuet } & \text { 'dance' } & 40 & 27 \% \\ \text { ubyt' } & \text { ot tebja ne ubudet } & \text { 'nothing is going to happen to you' } & 63 & 35 \% \\ \text { užit'sja } & \text { uživetsja } & \text { 'get on (with someone)' } & 34 & 24 \% \\ \text { ulučšit'sja } & \text { ulučšitsja } & \text { 'improve' } & 138 & 24 \% \\ \text { umen'šit'sja } & \text { umen'šitsja } & \text { 'decrease' } & 255 & 24 \% \\ \text { upravit'sja } & \text { upravitsja } & \text { 'take care of smth.' } & 159 & 41 \% \\ \text { utait' } & \text { utait } & \text { 'conceal' } & 65 & 30 \% \\ \text { utešit'sja } & \text { utešitsja } & \text { 'be comforted' } & 40 & 28 \% \\ \text { uxudšit' } & \text { uxudšit } & \text { 'get worse' } & 38 & 28 \% \\ \text { javljat'sja } & \text { javljaetsja } & \text { 'be' } & 39543 & 92 \%\end{array}$

